\title{
Identifying common genetic risk factors of diabetic neuropathies
}

\author{
Ini-Isabée Witzel ${ }^{1 *}$, Herbert F. Jelinek ${ }^{2,3}{ }^{3}$ Kinda Khalaf ${ }^{1}$, Sungmun Lee ${ }^{1}$, \\ Ahsan H. Khandoker ${ }^{1,4}$ and Habiba Alsafar ${ }^{1}$
}

${ }^{1}$ Biomedical Engineering Department, Khalifa University of Science, Technology and Research, Abu Dhabi, United Arab Emirates, ${ }^{2}$ Australian School of Advanced Medicine, Macquarie University, Sydney, NSW, Australia, ${ }^{3}$ Centre for Research in Complex Systems, School of Community Health, Charles Sturt University, Albury, NSW, Australia, ${ }^{4}$ Electrical and Electronic Engineering Department, The University of Melbourne, Parkville, VIC, Australia

\section{OPEN ACCESS}

Edited by: Gaetano Santulli,

Columbia University, USA

Reviewed by: Hiroki Mizukami,

Hirosaki University Graduate School of Medicine, Japan Antonino Tuttolomondo, University of Palermo, Italy

*Correspondence: Ini-Isabée Witzel, Biomedical Engineering Department, Khalifa University of Science, Technology and Research, PO Box 127788, Abu Dhabi, UAE ini.witzel@gmail.com

Specialty section: This article was submitted to Diabetes, a section of the journal Frontiers in Endocrinology

Received: 10 March 2015 Accepted: 13 May 2015 Published: 28 May 2015

Citation:

Witzel I-I, Jelinek HF, Khalaf K, Lee S, Khandoker AH and Alsafar H (2015) Identifying common genetic risk factors of diabetic neuropathies.

Front. Endocrinol. 6:88. doi: 10.3389/fendo.2015.00088
Type 2 diabetes mellitus (T2DM) is a global public health problem of epidemic proportions, with $60-70 \%$ of affected individuals suffering from associated neurovascular complications that act on multiple organ systems. The most common and clinically significant neuropathies of T2DM include uremic neuropathy, peripheral neuropathy, and cardiac autonomic neuropathy. These conditions seriously impact an individual's quality of life and significantly increase the risk of morbidity and mortality. Although advances in gene sequencing technologies have identified several genetic variants that may regulate the development and progression of T2DM, little is known about whether or not the variants are involved in disease progression and how these genetic variants are associated with diabetic neuropathy specifically. Significant missing heritability data and complex disease etiologies remain to be explained. This article is the first to provide a review of the genetic risk variants implicated in the diabetic neuropathies and to highlight potential commonalities. We thereby aim to contribute to the creation of a genetic-metabolic model that will help to elucidate the cause of diabetic neuropathies, evaluate a patient's risk profile, and ultimately facilitate preventative and targeted treatment for the individual.

Keywords: type 2 diabetes mellitus, diabetic complications, diabetic neuropathy, genetic factors, uremic neuropathy, diabetic peripheral neuropathy, cardiac autonomic neuropathy

\section{Introduction}

Diabetes mellitus is a worldwide public health problem that currently affects over 382 million people globally, and by 2025 this number is expected to rise to approximately 592 million (1). In 60-70\% of patients, diabetes is accompanied by neuropathies that can affect all organs of the body, and these complications are the key cause of morbidity and mortality among type 2 diabetes (T2DM) patients $(2,3)$. The mechanisms for the development of these neuropathies remain unclear, but are likely multifactorial and involve environmental and lifestyle factors, as well as genetic predisposition (4). This review is the first to consider the role of single and polygenetic influences in multiple

Abbreviations: ACEI, angiotensin-converting enzyme inhibitor; AGE, advanced glycation end-product; ARB, angiotensin receptor blocker; ARI, aldose reductase inhibitor; CAN, cardiac autonomic neuropathy; DN, diabetic nephropathy; DPN, diabetic peripheral neuropathy; GWAS, genome-wide association study; HRV, heart rate variability; I/D, insertion/deletion; LDL, low density lipoprotein; NGS, next generation sequencing; NO, nitric oxide; SNP, single nucleotide polymorphism; T1DM, type 1 diabetes mellitus; T2DM, type 2 diabetes mellitus; UN, uremic neuropathy; VLDL, very low density lipoprotein; VNTR, variable number tandem repeat. 
diabetic complications associated with neuropathy, with the aim to look for common genes that drive the development and progression of diabetic neuropathies. Early subclinical detection of diabetic neuropathy, by assessing genetic predisposition as well as metabolic control and physiology of diabetic patients, is critical in facilitating early intervention and prevention of the potentially serious consequences of diabetic neuropathy $(5,6)$.

The clinically most significant diabetic neuropathies are uremic neuropathy (UN), diabetic peripheral neuropathy (DPN), and cardiac autonomic neuropathy (CAN). Although these neuropathies may remain asymptomatic for prolonged periods, they seriously impact the quality of life of the affected individuals and pose an immense burden on public health systems, both in terms of human and economic costs as they contribute to the need for dialysis and renal transplantation, physical disability and amputations, and cardiac interventions. Diabetic neuropathies have complex disease etiologies, which are still not completely understood. Chronic hyperglycemia, hypertension, dyslipidemia, insulin resistance, and uremia are thought to be the key factors that contribute to their pathogenesis, as they cause changes in gene expression, molecular transport, inflammation, and oxidative stress (Figure 1). Genetic susceptibility and environmental factors are also known to interact and contribute significantly to disease onset and progression, which is evident in observations of twin studies and familial clustering, and in the variation of the prevalence and presentation of these complications among individuals, and among different ethnic groups (7-10).

Recent advances in the application of genome-wide association studies (GWAS) and next-generation sequencing (NGS) are expected to expedite and enhance the ability to identify genetic variants associated with complex diseases, such as T2DM and its associated neuropathies. Studies conducted to identify genetic risk factors of diabetic neuropathies still remain scarce, but over 60 loci have already been identified to influence the risk of developing T2DM (11). Despite this effort, a significant amount of missing heritability remains to be explained as the majority of studies published in this field are limited by a lack of reproducibility and insufficient statistical power. While the search continues for novel rare variants that may help explain this missing heritability, it is evident that diabetes and its associated complications are the

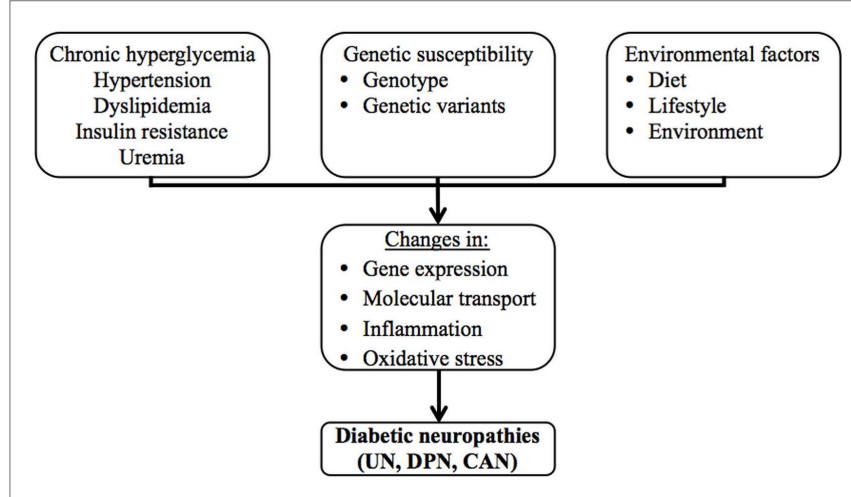

FIGURE 1 | The multifactorial etiology of the diabetic neuropathies. result of the combined effect of numerous genetic variants that may interact with each other and the environment to define disease risk, progression and severity. Complex interactions between risk factors contributing to the various diabetic neuropathies have been difficult to assess though, as the scope of diabetes-related genetic studies has often been limited to one particular candidate gene or one type of complication. GWAS conducted in this field so far have either focused on the risk of developing T2DM, or investigated risk factors of diabetes-associated retinal and renal vascular complications (12).

The pressing need to advance our understanding of the diabetic neuropathies is amplified by the rapidly increasing prevalence of T2DM and the associated increase in cardiovascular and kidney disease. UN and CAN remain underdiagnosed and there is an ongoing lack of effective treatment options for any of the diabetesassociated neuropathies. The main treatment approach for T2DMassociated neuropathies includes lifestyle changes and strict control of glucose and lipid levels, blood pressure control and addressing environmental factors (e.g., smoking), but these changes are often difficult to control, measure, or achieve and only have limited positive effects on slowing disease onset and progression (13-17). The only alternative treatment options are aimed at controlling pain and addressing the malfunctions of affected organs.

Diabetic neuropathy is a multifactorial disease that can affect the function of all organs of the body either directly or indirectly, mainly due to altered glucose metabolism, which affects neural tissue including central and peripheral nerves through oxidative stress mechanisms (18). Many of the genes and gene polymorphisms implicated in these complications to date are linked to glucose metabolism and biochemical changes, including inflammatory and immunological processes and hence may form a common genetic group that influences the development of diabetic complications. In order to allow us to target the diabetic neuropathies more effectively, future research needs to not only identify new genetic variants that contribute to each particular condition, but also to elucidate how such variants function and interact to give rise to the various diabetic neuropathies. By identifying commonalities, or differences, in the genes and proteins that determine the development and progression of the diabetic neuropathies, a deeper understanding of their complex disease etiologies will be gained, enabling the development of a more comprehensive approach to assessing an individual's risk profile and ultimately providing personalized, targeted treatment. To contribute to the creation of an integrated genetic-metabolic model of diabetic neuropathies, this review provides an original overview of the diabetic neuropathies UN, DPN, and CAN in T2DM patients, and discusses the common genetic risk variants that have been associated with these disease complications.

\section{Clinical Presentation of Diabetic Neuropathies}

\section{Uremic Neuropathy}

Approximately $30 \%$ of diabetic patients develop diabetic nephropathy (DN) and advanced renal failure, which are now the main cause of kidney failure in Western society (19). Diabetic nephropathy is also closely linked with the onset and progression 
of other diabetic neurovascular complications $(20,21)$. Advanced renal disease and renal failure lead to the release of uremic toxins. This uremia, combined with oxidative stress-related free radical activity, contributes to the damage of motor, sensory and autonomic nerves, making it a causative factor in the development of UN, DPN, and CAN $(22,23)$. In rare cases, the cranial nerves and pulmonary sympathetic nerves may also be affected (24-27). Approximately $60-100 \%$ of patients receiving dialysis treatment suffer from UN and the complication is more severe in diabetics than in non-diabetics $(17,28,29)$. The most common form of UN is a distal symmetric polyneuropathy in the lower limbs, which is due to length-dependent axonal degradation and secondary focal loss of myelin sheaths $(30,31)$.

Uremic neuropathy remains largely asymptomatic until renal function has decreased by approximately $75 \%$, when the glomerular filtration rate drops below $10-12 \mathrm{ml} / \mathrm{min}$, which may not occur until 10-15 years after the onset of DN (Table 1). At this advanced stage of renal disease, the symptoms rapidly progress in severity over months as serum creatinine levels build up (32). Early sensory symptoms include paresthesia, paradoxical heat sensation and increased pain sensation in the lower extremities $(33,34)$. Restless leg syndrome and cramps are common, and symptoms may move proximally and spread to upper extremities (35). As the disease progresses, motor neuropathy becomes evident as weakness, impaired deep tendon reflexes, imbalance, numbness, and atrophy of the lower limbs. Approximately half of uremic patients also experience autonomic impairment, evident in postural hypertension, hyperhidrosis, and dysfunction of the digestive, excretory. and reproductive organs $(17,27,36)$. However, clinical signs and symptoms due to UN, such as tingling in the feet, may be present much earlier (37).

Due to the prolonged asymptomatic nature of the condition, diagnosis often does not occur until significant damage has already taken place. Detailed neurological assessment and nerve conduction velocity testing are the most accurate way of diagnosing UN, even in asymptomatic patients (32). Afferent and efferent nerves regulate kidney function, and it is the renal sympathetic nerves that play an important role in kidney function and kidney homeostasis via renorenal reflex pathways. In T2DM and other pathologies, abnormal sympathetic modulation of the kidney contributes significantly to abnormal renal function (38). Autonomic dysfunction can be evaluated by monitoring cardiovascular reflex and heart rate variability (HRV) $(39,40)$. Only dialysis and renal transplantation are known to reverse the effects of UN and improve neural function. Unfortunately these interventions are themselves associated with similar neuropathic complications $(27,30)$.

\section{Diabetic Peripheral Neuropathy}

Approximately $50 \%$ of diabetic patients will develop DPN, which entails the risk of recurrent foot ulceration and potential amputation of lower extremities (Table 1) (41-44). The most common form of DPN is distal symmetrical polyneuropathy, which begins in the lower extremities and progresses to the upper limbs over time, giving rise to a "glove and stocking" pattern (5). Neuropathic pain, changes in sensitivity to vibration and thermal thresholds, as well as numbness is common characteristics of DPN (42). As the disease progresses, motor deficits, muscle weakness, and foot deformities may develop, affecting the individual's gait $(5,45)$. The combined effects of peripheral neuropathy, foot deformities, changes in foot biomechanics, and impaired turning of all major joints, contributes to significant postural sway and enhanced fall risk in comparison to healthy individuals. DPN has also been associated with symptoms of distal sympathetic autonomic neuropathy, which may become evident as dry, cracked, and warm skin and the appearance of plantar calluses at weight-bearing areas (46-49). Physical examination of the feet for calluses and ulcers, and monitoring for changes in sensory perception and muscle strength of the feet, may provide an early indication of the somatic neuropathy of DPN. No preventative treatment exists, but strict metabolic control is thought to slow down DPN progression.

\section{Cardiac Autonomic Neuropathy}

Cardiac autonomic neuropathy is thought to occur in $20-73 \%$ of T2DM patients, yet it often goes undiagnosed for several years (Table 1) (13). CAN alters cardiac rhythm through pathological changes, first occurring in the parasympathetic cardiac branches followed by sympathetic nervous system dysfunction, and thereby predisposes to cardiac arrhythmia $(40,50,51)$. In some populations, it has been shown to increase the 5 -year mortality risk by $50 \%$ ( 50 , $52-54)$. The presence and severity of UN and DPN have been associated with earlier onset and higher prevalence of CAN, supporting the close epidemiological link between these complications, but the concurrent development of somatic and autonomic neuropathies has also been reported in T2DM, with CAN developing during the pre-diabetic condition (55-60). The exact pathogenesis of CAN remains unclear and our understanding of neural damage relies largely on models of somatic neuropathy $(13,48)$. Chronic hyperglycemia, dyslipidemia, and oxidative stress are thought to contribute to accelerated nerve damage, neuronal ischemia, and the dysfunction and apoptosis of neurons $(13,51,61,62)$. CAN may be subclinical for many years, while parasympathetic denervation occurs. This results in an imbalance between parasympathetic and sympathetic tone, leading to changes in HRV as a marker of sympathovagal balance, alterations in baroreflex sensitivity, and abnormalities of the left ventricle (2,63-65). Within 5 years, CAN is thought to progress to sympathetic nerve damage, but the exact timeline is uncertain. In this clinical stage, patients experience resting tachycardia, exercise intolerance, postural hypotension, cardiac dysfunction, and diabetic cardiomyopathy (13).

Cardiovascular autonomic reflex tests can be used to monitor cardiac autonomic function by measuring changes in heart rate and blood pressure in response to deep respiration, the Valsalva maneuver and postural changes $(47,66,67)$. New techniques for cardiac imaging and guidance on diagnostic procedures are expected to improve the detection of subclinical CAN $(3,13)$. Intensive control of glycemia, lipidemia, hypertension, and lifestyle changes may reduce the risk of CAN by up to $50 \%$, but no therapeutic treatment exists that can prevent CAN completely $(13,62)$.

\section{Genetics of Diabetic Neuropathies}

The commonalities in the clinical presentation and molecular pathways known to be involved in UN, DPN, and CAN support 
TABLE 1 | Clinical presentation and management of the diabetic neuropathies.

\begin{tabular}{|c|c|c|c|}
\hline & $\begin{array}{l}\text { Uremic } \\
\text { neuropathy (UN) }\end{array}$ & $\begin{array}{l}\text { Diabetic peripheral } \\
\text { neuropathy (DPN) }\end{array}$ & $\begin{array}{l}\text { Cardiac autonomic } \\
\text { neuropathy (CAN) }\end{array}$ \\
\hline Affected nerves & $\begin{array}{l}\text { Distal symmetric polyneuropathy of sensory, } \\
\text { motor and autonomic nerves including renal } \\
\text { sympathetic nerves } \\
\text { In rare cases: cranial and pulmonary } \\
\text { sympathetic nerves }\end{array}$ & $\begin{array}{l}\text { Distal symmetric polyneuropathy of sensory } \\
\text { and motor nerves. Distal sympathetic } \\
\text { autonomic neuropathy may also be observed }\end{array}$ & $\begin{array}{l}\text { Parasympathetic and sympathetic } \\
\text { autonomic nerves of the heart and the } \\
\text { vasculature }\end{array}$ \\
\hline Pathogenesis & $\begin{array}{l}\text { Exact mechanism unclear } \\
\text { Advanced renal disease and build-up of uremic } \\
\text { toxins are thought to affect neuron function }\end{array}$ & $\begin{array}{l}\text { Exact mechanism unclear } \\
\text { Hyperglycemia is thought to affect } \\
\text { numerous pathways, causing nerve damage } \\
\text { and inhibiting repair mechanisms }\end{array}$ & $\begin{array}{l}\text { Exact mechanism unclear } \\
\text { Hyperglycemia is thought to lead to } \\
\text { accumulation of AGE products, which } \\
\text { signal through their receptor RAGE, } \\
\text { inducing chronic inflammation and } \\
\text { nerve damage }\end{array}$ \\
\hline Symptoms & $\begin{array}{l}\text { Early sensory symptoms } \\
\text { - Paresthesia } \\
\text { - Paradoxical heat sensation } \\
\text { - Increased pain sensation in lower extremities } \\
\text { - Restless leg syndrome } \\
\text { - Cramps } \\
\text { Advanced disease motor-deficit symptoms } \\
\text { - Muscle weakness } \\
\text { - Impaired deep tendon reflexes } \\
\text { - Imbalance } \\
\text { - Numbness } \\
\text { - Atrophy of lower limbs } \\
\text { Autonomic impairment } \\
\text { - Postural hypotension } \\
\text { - Hyperhidrosis } \\
\text { - Dysfunction of digestive, excretory and } \\
\text { reproductive organs }\end{array}$ & $\begin{array}{l}\text { Early sensory symptoms } \\
\text { - Neuropathic pain } \\
\text { - Sensitivity changes to vibration and } \\
\text { temperature } \\
\text { - Numbness } \\
\text { Advanced disease motor-deficit symptoms } \\
\text { - Muscle weakness } \\
\text { - Foot deformities } \\
\text { - Impaired deep tendon reflexes } \\
\text { - Imbalance } \\
\text { - Changes in gait and postural sway } \\
\text { Distal sympathetic autonomic neuropathy } \\
\text { - Dry, cracked and warm skin } \\
\text { - Plantar calluses at weight-bearing areas }\end{array}$ & $\begin{array}{l}\text { Subclinical stage } \\
\text { - Parasympathetic and sympathetic } \\
\text { tone imbalance } \\
\text { - HRV changes } \\
\text { - Alterations in baroreflex sensitivity } \\
\text { - Abnormalities in left ventricle } \\
\text { Clinical stage } \\
\text { - Resting tachycardia } \\
\text { - Exercise intolerance } \\
\text { - Postural hypotension } \\
\text { - Cardiac dysfunction } \\
\text { - Diabetic cardiomyopathy }\end{array}$ \\
\hline $\begin{array}{l}\text { Diagnosis of somatic } \\
\text { neuropathy }\end{array}$ & $\begin{array}{l}\text { - Neurological assessment } \\
\text { - Nerve conduction velocity testing }\end{array}$ & $\begin{array}{l}\text { - Physical examination of feet } \\
\text { - Perception of vibration, temperature, pain } \\
\text { - Ankle reflex }\end{array}$ & \\
\hline $\begin{array}{l}\text { Diagnosis of autonomic } \\
\text { neuropathy }\end{array}$ & $\begin{array}{l}\text { - } \text { Cardiovascular autonomic } \\
\text { reflex tests } \\
\text { - HRV }\end{array}$ & $\begin{array}{l}\text { - Foot muscle strength } \\
\text { - Cardiovascular autonomic reflex tests } \\
\text { - HRV }\end{array}$ & $\begin{array}{l}\text { - Cardiovascular autonomic reflex tests } \\
\text { - HRV }\end{array}$ \\
\hline Treatment & $\begin{array}{l}\text { No preventative treatment } \\
\text { Dialysis and renal transplantation }\end{array}$ & $\begin{array}{l}\text { No preventative treatment } \\
\text { Intensive control of glycemia, lipidemia, } \\
\text { hypertension and lifestyle changes } \\
\text { reduce risk }\end{array}$ & $\begin{array}{l}\text { No preventative treatment } \\
\text { Intensive control of glycemia, lipidemia, } \\
\text { hypertension and lifestyle changes } \\
\text { reduce risk }\end{array}$ \\
\hline
\end{tabular}

a close epidemiological link between these diabetic neuropathies, and the presence of one neuropathy frequently increases the risk of onset or severity of another $(68,69)$. Only a small number of studies have been carried out to investigate the genetic predisposition to these neuropathies in T2DM patients.

\section{Genetics of Uremic Neuropathy}

Considering the increasing prevalence and severe implications of chronic kidney disease, it is not surprising that an extensive number of studies have been carried out to identify genetic variants that may contribute to renal disease, including $\mathrm{DN}$, but far less is known of the genetics of UN. MalaCards, the human malady compendium database, lists four genes related to $\mathrm{UN}$ : B2M, PTH, PSMC2, and PNRC1 (70). Beta-2-microglobulin (B2M) has been extensively studied in relation to diabetes, kidney disease, and cardiac events. In T2DM, it acts as a sensitive diagnostic marker for renal function; it is considered a uremic toxin and is also used as a surrogate marker for other uremic toxins (71-73). Elevated B2M plasma levels have been associated with cardiovascular disease and mortality in uremic patients (71). Parathyroid hormone (PTH) has also been implicated in several chronic complications of diabetes including retinopathy and nephropathy, as well as in renal disease in non-diabetics (74-76). It is considered a major uremic toxin, and variations in PTH levels have been associated with $\mathrm{UN}(77,78)$. In a study conducted in non-diabetic dialysis patients, PTH levels were not found to be associated with autonomic dysfunction; to our knowledge this association has not been tested in diabetics (14, 79). Whether the genes identified by two GWAS linking DN with T2DM are also involved in UN is not clear (80-82). Statistically significant associations have been detected between DN in T2DM and single nucleotide polymorphisms (SNPs) in genes including ACACB (83), ACE (84), ADIPOR2 (85), AGER (RAGE) (85), AGTR1 (86), AGT (86), AKR1B1 (87), APOE (88), CCL5 (RANTES), and its receptor CCR5 (89, 90), CNDP1 (91), CYBA (92), ELMO1 (93), 
FABP-2 (94), FRMD3 (95), HSPG2 (85), IL-6 (96), KCNQ1 (97), LPL (88), MMP9 (98), MTHFR (99), MYH9 (100), NCALD (80, 101), NOS3 (85), and PPARY2 (102), PVT1 (103), SIRT1 (104), SLC12A3 (80, 105), VEGF (106), rs1411766 (chromosome 13q) (107), rs1034589 (nearest gene: RNF185) (81), and several SNPs within the LIMK2-SF1 region (81). Numerous candidate genes could be added to this list by including polymorphisms that have been shown to have a marginally significant association with $\mathrm{DN}$, and gene expression studies that have associated $\mathrm{DN}$ with changes in expression levels of miRNAs and members of the NF- $\mathrm{kB}$, TGF$\beta 1$ and complement pathways $(19,81,85,108-113)$.

\section{Genetics of Diabetic Peripheral Neuropathy}

Numerous studies have investigated genetic risk and protective factors for DPN in T2DM in particular, highlighting a potential association with specific polymorphisms in genes including ACE (114), AKR1B1 (115), ADRA2B (116), APOE (117-119), GPx-1 (120), IL-4 (121), IL-10 (122), IFN- $\gamma$ (122), MTHFR (123), NOS1AP (124), NOS3 (125-127), TLR4 (128), UCP2 (129), and VEGF (Table 2) (130). Variants of mitochondrial genes have also been linked to T2DM, and recently polymorphisms in ATPase 8, $N D 1, N D 5$, and $M T-C Y B$ were suggested to affect DPN based on a study of a single individual (131). Further candidate genes have been proposed, based on their role in regulating DPN in type 1 diabetes (T1DM).

\section{Genetics of Cardiac Autonomic Neuropathy}

Studies on genetic variants involved in CAN remain scarce and potential candidate genes are often selected based on their implication in somatic peripheral neuropathies. A number of genes have been linked to CAN in particular, based on their involvement in autonomic dysfunction in animal models and in human patients of T1DM or other cardiac complication, or due to their involvement in inflammatory responses that are thought to contribute to neuronal injury. These candidate genes include ACE (134), ADRB2 (135), AKR1B1 (47, 136), APOE (137), CAT (138), GNAS (139), MTHFR (140), NF-KB (141), NOS (142, 143), TLR2 and TLR4 (144), and SREBP-1 (145). The only genetic polymorphisms that have been associated with the risk of CAN in T2DM patients are TCF7L2 (9), TNF- $\alpha(133,146)$, and CHT1 (Table 2) (132). Serum levels of interleukin 6 (IL-6) $(147,148)$ and adiponectin (ADIPOQ) (146) have also shown to change with CAN in T2DM patients, but no genetic variants have been linked to this observation. The heritability of CAN-related parameters has been associated particularly with variants of the $A C E$ gene, but twin studies in non-diabetic subjects have produced contradictory results with regards to the effect size imposed by genetic and environmental factors on CAN risk (10, 149-151).

\section{Common Genetic Risk Factors}

This review highlights the lack of studies conducted to investigate the genetic risk factors that contribute to diabetic neuropathies, particularly UN, DPN, and CAN. Based on the publications identified in this review, polymorphisms within $A C E, A K R 1 B 1$, APOE, MTHFR, NOS3, and VEGF have been shown to contribute to DPN as well as DN. Considering the functions of these genes, it is possible that these same variants also contribute to UN and
CAN (Figure 2). If one also considers candidate genes that have been implied in but not significantly associated with the diabetic neuropathies, this list of potentially common risk factors could be extended significantly. The implication of these candidate genes comes as no surprise as all of them are associated with key molecular pathways that have been linked to diabetes and its complications $(48,50,152)$. This observation warrants further investigation into how exactly these genetic variants may contribute to the diabetic neuropathies, and what their pharmacogenetic effects may be.

\section{ACE}

The ACE gene encodes the angiotensin-converting enzyme, which is a key component of the renin-angiotensin system. It is a potent vasoconstrictor that converts angiotensin I to angiotensin II, and is involved in inducing proteolysis of the vasodilator bradykinin 2 (153-155). Angiotensin II is attributed a role in the regulation of glucose and insulin levels, and the hyperglycemia-induced increase in angiotensin II levels has been linked to diabetes risk and found to induce oxidative stress, damage to endothelial cells, inflammation, vascular changes, and thrombosis (Figure 2) (156-158). The insertion/deletion (I/D) polymorphism of a 287 base pair Alu sequence in intron 16 of the ACE gene is of particular interest, as this polymorphism alone is thought to be responsible for $46 \%$ of the variance of the ACE enzyme present in serum $(159,160)$. The deletion variant $\mathrm{D}$, and the $\mathrm{DD}$ genotype in particular, has been associated with significantly higher plasma levels of ACE (161, 162). In DPN, the $A C E I / D$ polymorphism has been identified as a genetic risk factor (Table 1) $(114,163)$. No studies have investigated the association between $A C E$ and $\mathrm{UN}$, but the renin-angiotensin system and its component angiotensin II are thought to contribute to most pathological processes involved in $\mathrm{DN}$ and therefore may also be contributing to UN $(164,165)$. This is supported by several meta-analyses that suggest that the $\mathrm{D}$ allele is a risk factor for DN (166-168); the I/I genotype is thought to fulfill a protective function in this regard (169). The ACE I/D polymorphism alone, and haplotypes including this and other markers within the ACE gene, have been associated with DN progression and end stage renal disease in particular, which in turn leads to UN (84, 170-172). The ACE D/D genotype has also been linked with impaired circadian blood pressure variation in T2DM, which is associated with autonomic neuropathy, hypertension, and limited kidney function $(134,173)$. Studies investigating the association between the ACE I/D polymorphism and diabetic complications have produced very contradictory results, providing a good example of an issue encountered in the majority of genetic studies of T2DM risk factors. These contradictions have been attributed to inter-ethnic variation of allele distribution, and a lack of consideration for haplotypes and linkage disequilibrium that exists between different genetic variants across the $A C E$ gene $(172,174)$.

The ACE I/D variant is also thought to affect a patient's response to therapeutics commonly used in diabetes: angiotensin-converting enzyme inhibitors (ACEIs) and angiotensin receptor blockers (ARBs) are used to treat hypertension and numerous diabetic complications including retinopathy, nephropathy, neuropathy, CAN, and cardiovascular disease (175-181). The polymorphism has also been reported to affect the efficiency of statins used to treat hypercholesterolemia (182). Contradictory results have 
TABLE 2 | Genetic variants showing a significant association with diabetic neuropathies in T2DM.

\begin{tabular}{|c|c|c|c|c|c|}
\hline Gene & SNP/variant & Risk variant & Sample size & Ethnic group & Reference \\
\hline \multicolumn{6}{|c|}{ A. Diabetic peripheral neuropathy (DPN) } \\
\hline$A C E$ & I/D (287 bp, intron 19) & $\mathrm{D}$ & 1316 T2DM patients with DPN, 1617 controls & Caucasians and Asians & $(114)$ \\
\hline AKR1B1 & $\begin{array}{l}-106 \mathrm{C} / \mathrm{T} \\
(\mathrm{CA}) n \text { repeat (Z allele, } \\
n=24)\end{array}$ & $\begin{array}{l}\mathrm{T} \\
\mathrm{Z}-2\end{array}$ & $\begin{array}{l}85 \text { T2DM patients, } \\
126 \text { non-diabetic controls }\end{array}$ & Finnish & $(115)$ \\
\hline Alpha 2B-AR & l/D & $\mathrm{D}$ & $\begin{array}{l}130 \text { T2DM patients with DPN, } \\
60 \text { T2DM patients without DPN }\end{array}$ & Greek & $(116)$ \\
\hline APOE & rs429358 T/C, rs7412 C/T & $\mathrm{C} / \mathrm{C}$ & 158 T2DM patients & Japanese & $(117)$ \\
\hline GPx-1 & rs1050450 C/T & $\mathrm{T}$ & 1155 T1DM and T2DM patients & Caucasian & $(120)$ \\
\hline $\mathrm{IL}-4$ & VNTR (P1/P2 allele) & P1 allele & $\begin{array}{l}227 \text { T1DM and T2DM patients with DPN, } \\
241 \text { non-diabetic controls }\end{array}$ & Turkish & $(121)$ \\
\hline IL-10 & $-1082 \mathrm{G} / \mathrm{A}$ & $\mathrm{G}$ & 198 T2DM patients, 202 non-diabetic controls & South Indian & $(122)$ \\
\hline $\mathrm{IFN}-\gamma$ & $874 \mathrm{~A} / \mathrm{T}$ & A & 198 T2DM patients, 202 non-diabetic controls & South Indian & $(122)$ \\
\hline MTHFR & $677 \mathrm{C} / \mathrm{T}$ & $\mathrm{T}$ & $\begin{array}{l}230 \text { T1DM and T2DM patients with DPN, } \\
282 \text { Non-diabetic controls }\end{array}$ & Turkish & $(123)$ \\
\hline NOS1AP & $\begin{array}{l}\text { rs1963645 A/G } \\
\text { rs6659759 T/C } \\
\text { rs16849113 C/T } \\
\text { rs880296 C/G }\end{array}$ & $\begin{array}{l}\mathrm{G} \\
\mathrm{C} \\
\mathrm{T} \\
\mathrm{G}\end{array}$ & $\begin{array}{l}26 \text { Diabetic patients with CKD } \\
21 \text { Non-diabetics with CKD } \\
30 \text { Diabetic patients with CKD } \\
20 \text { Non-diabetics with CKD }\end{array}$ & $\begin{array}{l}\text { White American } \\
\text { African } \\
\text { American }\end{array}$ & $(124)$ \\
\hline NOS3 & $\begin{array}{l}27 \mathrm{VNTR}(4 \mathrm{a} / \mathrm{b}) \\
-786 \mathrm{~T} / \mathrm{C}(\mathrm{rs} 270744)\end{array}$ & $\begin{array}{l}4 a \\
C\end{array}$ & $\begin{array}{l}353 \text { T2DM patients with DPN } \\
905 \text { T2DM patients without DPN }\end{array}$ & North and South Indian & $(125)$ \\
\hline TLR4 & $\begin{array}{l}896 \mathrm{~A} / \mathrm{G}(\mathrm{rs} 4986790) \\
1196 \mathrm{C} / \mathrm{T}\end{array}$ & $\begin{array}{l}\mathrm{AA} \\
\mathrm{CC}\end{array}$ & 246 T1DM patients, 530 T2DM patients & German Caucasian & $(128)$ \\
\hline UCP2 & $-866 \mathrm{G} / \mathrm{A}$ & A & 197 T2DM patients & Japanese & $(129)$ \\
\hline VEGF & I/D (18bp, at -2549) & $\mathrm{D}$ & $\begin{array}{l}84 \text { T2DM patients with DPN, } \\
90 \text { Non-diabetic controls }\end{array}$ & Romanian & $(130)$ \\
\hline \multicolumn{6}{|c|}{ B. Cardiac autonomic neuropathy (CAN) } \\
\hline CHT1 & SNP in $3^{\prime} U T R$ & $\mathrm{~T}$ & 95 T2DM patients, 208 non-diabetic controls & African Americans & $(132)$ \\
\hline TCF7L2 & $\begin{array}{l}\text { rs7903146 C/T } \\
\text { rs7901695 T/C }\end{array}$ & $\begin{array}{l}\mathrm{T} \\
\mathrm{C}\end{array}$ & 154 T2DM patients, 185 non-diabetic controls & Italian & (9) \\
\hline $\mathrm{TCF}-\alpha$ & $-308 \mathrm{~A} / \mathrm{G}$ & A & $\begin{array}{l}\text { eight diabetic patients with congestive heart } \\
\text { failure, three healthy controls }\end{array}$ & Serbian & $(133)$ \\
\hline
\end{tabular}

Several genes and their genetic variants have been associated with diabetic peripheral neuropathy (DPN, A) and cardiac autonomic neuropathy (CAN, B) in type 2 diabetes mellitus (T2DM). This table lists the first publications to identify a statistically significant association between these genetic variants and the diabetic neuropathy, or refers to a recent metaanalysis if too many contradictory publications were found on the topic. bp, base pair; CKD, chronic kidney disease; SNP, single nucleotide polymorphism; T1DM, type 1 diabetes mellitus; T2DM, type 2 diabetes mellitus; UTR, untranslated region.

been published on either the II or DD genotype facilitating a better treatment outcome and due to these inconsistencies, and a lack of sufficient genetic data, no consensus has been reached on the benefit of routinely genotyping patients for the ACE I/D polymorphism $(176,182-187)$.

\section{AKR1B1}

Aldose reductase is the first rate-limiting enzyme in the polyol pathway, which reduces glucose to sorbitol in an NADPHdependent reaction. In hyperglycemic conditions, an increased flux of glucose through the polyol pathway has been shown to contribute to diabetic neurovascular complications by depleting NADPH levels and reducing a cell's antioxidant capacity by increasing the formation of advanced glycation end products (AGEs), and contributing to oxidative and osmotic stress (Figure 2) (188). Polymorphisms within the aldose reductase gene, $A K R 1 B 1$, and its promoter region have been linked to diabetic neuropathies and microvascular complications (115, 189). These include the (CA) $n$ microsatellite $(n=22-29 ; \mathrm{Z}$ allele $n=24$ ) located approximately $2.1 \mathrm{~kb}$ upstream of the gene's transcription start site, and two polymorphisms in the basal promoter region at $-106 \mathrm{C} / \mathrm{T}(\mathrm{rs} 759853)$ and $-12 \mathrm{G} / \mathrm{C}$. The (CA) $n$ Z-2 and the $-106 \mathrm{C} / \mathrm{T}$ polymorphisms have been found to be closely linked (115). Patients suffering from diabetic neurovascular complications have been shown to express higher levels of aldose reductase; a haplotype including the microsatellite Z-2 and SNP -106 C variants has been associated with the highest expression levels of $A K R 1 B 1$ and is thought to pose a high risk for diabetic microvascular complications (190). In T2DM patients with DN, the Z-2 and $-106 \mathrm{~T}$ alleles have been shown to have a synergistic effect on increasing the risk of patients suffering cardio-renal endpoints $(191,192)$. The overexpression of AKR1B1 has not only been reported in glomeruli, but also in the peripheral nerves of T2DM patients, where it is thought to contribute to 


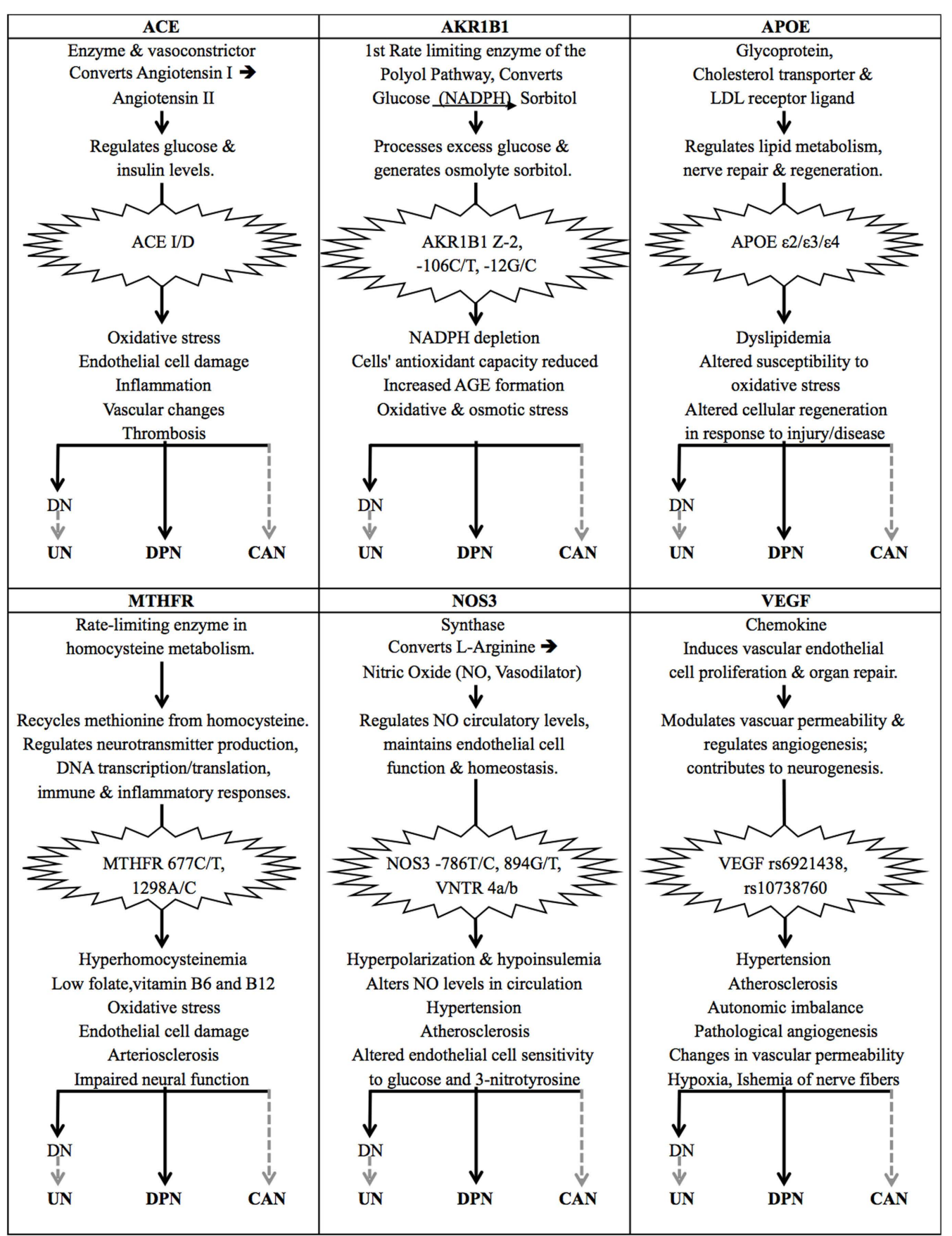

FIGURE 2 | The effects of common genetic variants implicated in the diabetic neuropathies. The gene products of ACE, AKR1B1, APOE, MTHFR, NOS3, and VEGF are all involved in important molecular pathways that have been associated with type 2 diabetes (T2DM) and diabetic neuropathies. Certain genetic variants of these genes have been identified as risk factors for diabetic nephropathy (DN) and diabetic peripheral neuropathy (DPN) in particular. DN causes renal damage and a build-up of uremic toxins, which is thought to lead to uremic neuropathy $(\mathrm{UN})$, suggesting that these genetic risk factors also affect the onset and progression of UN. The same genetic variants have also been implied in diabetic autonomic neuropathy and cardiac complications, suggesting their involvement in CAN, but their direct association with CAN in T2DM patients remains to be proven. Solid black arrows indicate that a statistically significant association has been published; dashed gray arrows indicate a suspected association. the disease pathology of diabetic neuropathy $(193,194)$. T2DM patients with the AKR1B1 -106 T/T genotype have been reported to experience more severe neuropathological deterioration in the sural and radial nerves, contributing to the onset of DPN (115).
The Z-2 variant has not been found to significantly affect DPN to date $(115,195)$. AKR1B1 variants have been associated with CAN in T1DM patients, but no association has been shown in individuals with T2DM $(47,195,196)$. 
Aldose reductase inhibitors (ARIs) have been researched over many years for their use in treating diabetic complications, but although animal studies have provided promising results, clinical trials in search of an optimal ARI for humans continues (197-206). Only Epalrestat is currently on the market in Japan to treat DPNassociated symptoms (198, 207, 208). Epalrestat has also been reported to delay progression of diabetic retinopathy, nephropathy, and neuropathy, and has been suggested as a treatment for CAN (207-209). As polymorphisms of $A K R 1 B 1$ affect aldose reductase expression levels, it is suspected that these polymorphisms may affect a patient's optimum dosage of ARIs, but this remains to be investigated.

\section{APOE}

The apolipoprotein $\mathrm{E}$ (apoE) gene product is a cholesterol transport protein and a major ligand of the low density lipoprotein (LDL) receptor, which plays an important role in lipid metabolism, hypercholesterolemia, as well as nerve repair and regeneration (Figure 2) $(210,211)$. The APOE gene has three main alleles, which are the result of two SNPs that cause amino acid changes at 112 Cys/Arg (rs429358 C/T) and 158 Arg/Cys (rs7412 T/C). The $\varepsilon 3$ variant is the most common and has the wild type alleles at both SNPs; the $\varepsilon 4$ allele has a substitution giving rise to an arginine at amino acid 112, and the least common allele, $\varepsilon 2$, has a substitution leading to a cysteine at amino acid 158 (212). These alleles give rise to the apoE2, E3, and E4 protein isoforms, which differ in charge and stability, and their roles in various disease pathologies. The $\varepsilon 2$ allele is thought to result in higher circulatory levels of apoE, but lower levels of LDL cholesterol. It has been shown to be defective in binding the LDL receptor, but has been suggested to protect against micro- and macro-vascular complications in T2DM $(213,214)$. The $\varepsilon 4$ variant has been associated with lower levels of circulatory apoE, but higher plasma levels of total cholesterol, LDL, and VLDL (very low density lipoprotein), and has been associated with higher risk and severity of neuropathological diseases (119,214-216). Contradictory results have been obtained with regards to the role of $A P O E$ variants in diabetes, which may be due to population-specific effects and variations in study designs (210). APOE polymorphisms have been linked to DN risk, but no definite conclusion has been made on whether the $\varepsilon 2$ or $\varepsilon 4$ allele confers disease risk (217). The APOE variants have been implicated in neurological disorders of the central and peripheral nervous system, yet results on their role as a risk or protective factor in DPN have also been inconsistent and a recent meta-analysis could not establish a definite association $(119,212)$. Several studies have shown that the $A P O E \& 4$ allele may be associated with particularly severe DPN (117-119). Interestingly, the APOE \&2 allele was associated with lower levels of DPN in most published studies, and may have a protective role in neuromuscular diseases (118, $119,212,218)$. Based on the association of APOE and its $\varepsilon 4$ allele with disorders of the nervous system, as well as observations made in $A P O E(-/-)$ knockout mice, it is considered a candidate gene for CAN risk, but no association has been published $(50,137,219)$.

Pharmacogenetic effects of the APOE genotype have also been found in response to therapeutic approaches used in diabetes, hyperlipidemia, and neurodegenerative diseases (220-223). Metformin has been found to enhance $A P O E$ expression, which is known to affect peripheral nerve regeneration $(220,224,225)$; if this effect is isoform specific is unclear. APOE genetic variants have been reported to respond differently to diet therapy and lipidlowering therapy using statins. Some studies suggest that carriers of the $\varepsilon 4$ isoform are less responsive to statins, but more responsive to diet and lifestyle interventions. However controversial results have also been published and no consensus has been reached with regards to routine APOE genotyping (163, 210, 221, 223, 226-229).

\section{MTHFR}

The 5,10-methylene-tetrahydrofolate reductase (MTHFR) enzyme and its genetic variants have been implicated in various disease pathologies. The two most studied missense mutations, $677 \mathrm{C} / \mathrm{T}$ (rs1801133) and 1298 A/C (rs1801131), have been associated with T2DM and diabetic neuropathies, independently and in synergy (230). Both polymorphism leads to a reduced enzyme activity of MTHFR, which has been linked to hyperhomocysteinemia (elevated plasma levels of homocysteine) and lower levels of folate, and vitamins B6, and B12 (230-233). At least 35\% of this variation in homocysteine levels is thought to be due to folate and vitamin B12 levels, and a change in diet may counteract the negative effects of the $677 \mathrm{C} / \mathrm{T}$ polymorphism to some extent $(234,235)$. This indicates that diet is a confounding factor that should be considered in MTHFR studies. Hyperhomocysteinemia has been shown to induce oxidative damage of endothelial cells, arteriosclerosis, and impaired neural function $(236,237)$, and has been associated with neurovascular diabetic complications $(238,239)$. The $677 \mathrm{C} / \mathrm{T}$ variant has been linked to DPN $(123,237$, 240). Albuminuria, glomerular lesions, and DN in T2DM have also been linked to hyperhomocysteinemia and the $677 \mathrm{~T}$ allele, but no direct association with UN has been made (237, 241-243). Elevated homocysteine level is also considered a risk factor for diabetic autonomic neuropathy (244). No studies investigated the role of MTHFR polymorphisms in relation to CAN specifically, but in a non-diabetic study, the $677 \mathrm{~T}$ allele was linked to lower HRV than the CC genotype, which is a diagnostic indicator of CAN (140).

Mutations of the MTHFR gene have been found to affect a patient's response to numerous drugs, including metformin, nitrous oxide anesthesia, methotrexate, and chemotherapy (245-249). In diabetics, metformin treatment has been linked to vitamin B12 deficiency; this vitamin deficiency may in turn cause hyperhomocysteinemia, which is exacerbated in patients with the $677 \mathrm{C} / \mathrm{T}$ mutation and increases the risk of DPN, diabetic retinopathy, and vascular thrombosis (250-252). In the presence of the $677 \mathrm{C} / \mathrm{T}$ and $1298 \mathrm{~A} / \mathrm{C}$ polymorphisms of MTHFR, treatment with MTHFR-5, vitamins (such as folic acid) and minerals are suggested to supplement the deficient enzyme $(246,251)$.

\section{NOS3}

Nitric oxide (NO) is produced from L-arginine by endothelial nitric oxide synthase (NOS3 or eNOS) and functions as a vasodilator that is essential for the maintenance of endothelial cell function and homeostasis (Figure 2) (253). Genetic variants of NOS3 have been linked to changes in circulating levels of NO and have been implicated in hypertension, atherosclerosis, and diabetic microvascular complications (254). Three polymorphisms within this gene have been of particular interest as they have been shown to alter NOS3 
enzyme activity and plasma levels of NO: the -786 T/C (rs2070744) and $894 \mathrm{G} / \mathrm{T}$ (rs1799983) SNPs, as well as the variable number tandem repeat (VNTR) polymorphism within intron 4 that can give rise to two deletion variants, $4 \mathrm{a}$ and $4 \mathrm{~b}$. The regulation of NOS3 is complicated by strong linkage that exists between several SNPs within the gene, as well as potential interactions of these alleles with other genetic variants (255). Numerous studies have linked these three polymorphisms of NOS3 and related haplotypes with the development and progression of DN $(256,257)$. No association with UN has been made, but NO and the nitric oxide synthases are known to fulfill important functions in the peripheral nervous system. Several recent studies have implicated NOS3 variants in DPN. Particularly the NOS3 VNTR 4a/b variant is suspected of having a haplotype-dependent effect on diabetic microvascular complications and diabetic neuropathy (258). Many contradictory results have been reported on the role of NOS 3 variants in relation to diabetic neuropathies as they seem to be significantly influenced by population-specific effects (125-127). Nitric oxide is also an important regulator of the autonomic nervous system and the NOS3 $-786 \mathrm{~T} / \mathrm{C}$ variant has been found to contribute to autonomic imbalance in various disease pathologies, but it has not yet been associated with CAN in T2DM in particular (143).

The association of NOS3 with neuropathic pain and inflammation makes it an interesting therapeutic target (259). As the NOS3 polymorphisms discussed here affect NOS3 enzyme activity as well as NO plasma levels, they may need to be considered during drug design and dosage. L-arginine supplementation has been tested to restore NO levels in diabetes, but contradictory results about the effectiveness of this NO precursor have been published and whether NOS3 polymorphisms have an effect on this supplementation remains unclear (260-263).

\section{VEGF}

The vascular endothelial growth factor (VEGF) is a chemokine that induces vascular endothelial cell proliferation and organ repair. It plays a key role in modulating vascular permeability and regulating angiogenesis, and numerous studies have highlighted its positive contribution to neurogenesis $(264,265)$. A significant level of heritability has been found to affect VEGF levels in circulation, up to $60-80 \%$, of which $50 \%$ are determined by its SNPs rs 6921438 and rs10738760 (266-269). Although several studies suggest that an upregulation of VEGF may fulfill a protective and neurotropic function, and that administration of VEGF may improve diabetic neuropathy, other studies show that an increase in circulating VEGF levels is associated with pathological angiogenesis and changes in vascular permeability, thereby contributing to cardiovascular and diabetic complications, ischemia of nerve fibers and hypoxia (Figure 2) (48, 270-274). In DN, the contradictory effects of VEGF may be explained by VEGF potentially fulfilling different functions during disease onset and progression, and in diabetics versus nondiabetics (275). VEGF polymorphisms have been linked to the risk of developing DN, but no significant association could be detected between VEGF polymorphisms and UN or DPN so far $(106,276)$.

Anti-VEGF antibodies, or antibody fragments, are currently only being used to treat diabetic retinopathy and macular edema $(277,278)$. Studies in non-diabetic patients with age-related macular degeneration have suggested that polymorphisms of VEGF contribute to the variability in response to anti-VEGF treatment, but contradictory results have been published (279-286). With regards to neuropathy treatment, gene transfer of VEGF is being investigated $(287,288)$.

\section{Conclusion}

Type 2 diabetes mellitus is associated with the risk of developing debilitating and life-threatening neurovascular complications including UN, DPN, and CAN. While recent advances in genetic research tools have already provided us with a wealth of data on genetic variants that may affect an individual's risk of developing diabetes and its associated retinal and renal vascular complications, little research has been conducted in the area of diabetic neuropathies. As new NGS developments drive the search for rare genetic variants that may explain the missing heritability of T2DM, it is important to not lose sight of the need to further investigate the variants we have already identified. How do these genetic variants function and interact in the various diabetic neuropathies? How can we use this knowledge to assess an individual's risk of diabetic neuropathy? And ultimately, how can we apply this information to provide patients with targeted, personalized treatment? Most studies of T2DM genetics investigate polymorphisms and single gene effects in the diabetic population in general, irrespective of the patients' complications, or they only focus on one diabetic complication in particular. Yet, we are already aware of common risk factors contributing to the various diabetic complications. Recent reviews by Tang et al. (111) and Forbes \& Cooper (152) have provided a comprehensive overview of the genetic and molecular pathways contributing to T2DM and its vascular complications, highlighting commonalities between the different conditions. To our knowledge, our review is the first to provide an overview of common genetic variants that contribute to the diabetic neuropathies, including UN, DPN, and CAN.

Extensive research in the areas of chronic kidney disease, peripheral neuropathy, and atherosclerosis has given rise to a substantial list of genetic variants that may be associated with these conditions, paving the way for research into their role in diabetic neuropathy. This review suggests that polymorphism within ACE, AKR1B1, APOE, MTHFR, NOS3, and VEGF may act as common genetic risk factors for the diabetic neuropathies in T2DM (Figure 2). Numerous other genetic variants have been implicated, yet not significantly associated with all of UN, DPN, and CAN. Polymorphisms in genes of the inflammatory and thrombotic pathways, as well as the plasma levels of the resulting gene products including, CD40 ligand and MCP-1, may be of particular interest to future studies, as these processes have been implicated in the development of nerve damage in several diabetic neuropathies and have also been linked to other diabetic complications including ischemic stroke (289-291). More research is required, especially in the field of $\mathrm{UN}$, to elucidate the possible synergistic effects of gene products. There may be common genetic variants associated with both CAN and UN, which may be difficult to disentangle as both CAN and UN have a pre-clinical phase that can be present early in diabetic disease progression and even at the pre-diabetic stage. The identification of genetic risk factors may be further complicated by the fact that genes that play a role in the 
diverse biochemical pathways associated with the development of diabetic neuropathy, including oxidative stress, AGE products and the polyol pathway, may be selectively turned on or off depending on the stage of disease progression.

Another interesting area of research, with regards to the genetics of diabetic neuropathies, is the field of pharmacogenetics. Treatment options for gene related products is an important new direction for therapy, which is gaining momentum with the identification of gene variants being associated with diabetic complications. It is important to note that genetic polymorphisms, such as the ones discussed in this review, may modify a patient's response to medication. Further genetic data will be essential to verify the possible benefits of routine genotyping, and the pharmacogenetics that may guide personalized medication, dosage and delivery.

In addition to increasing research efforts with regards to the diabetic neuropathies, methodological issues experienced by genetic studies also need to be tackled. When one reviews the literature published on genetic risk factors of T2DM and the diabetic complications, major issues such as the lack of reproducibility and insufficient statistical power are very apparent. These shortcomings can be largely attributed to small samples sizes, population-specific effects and the significant heterogeneity between study designs. The generation of standards and guidelines on the definition and diagnosis of the different neuropathies, and a better understanding of what confounding factors or comorbidities must be taken into account, will hopefully reduce this variation and improve our ability to generate more reproducible results. Taking into consideration the effect of haplotypes, linkage disequilibrium, and gene-environment interactions may also explain a significant part of this variation. By reducing the heterogeneity between studies, meta-analysis would be more applicable and could help increase the statistical power by combining smaller datasets. Advances in NGS are also expected to enhance the statistical power of studies, but the use of sufficiently large sample sizes continues to be paramount, as many studies still include less than 100 subjects. Inter-ethnic differences in allele frequencies have also been identified for most genetic variants, which points toward the need for population-specific studies. Ultimately, even when genetic variants alone do not indicate a significant association with a condition, associated changes in gene expression and regulation may still identify the variant's product as a useful biomarker. Genetic variants should not be viewed in isolation; and neither should the diabetic neuropathies.

To further our understanding of UN, DPN, and CAN in T2DM, we suggest that whole genome analysis will be required

\section{References}

1. International Diabetes Federation. IDF Diabetes Atlas [Internet]. 6th ed. (2013). Available from: http://www.idf.org/diabetesatlas

2. Khandoker AH, Jelinek HF, Moritani T, Palaniswami M. Association of cardiac autonomic neuropathy with alteration of sympatho-vagal balance through heart rate variability analysis. Med Eng Phys (2010) 32(2):161-7. doi:10.1016/j. medengphy.2009.11.005

3. Spallone V, Ziegler D, Freeman R, Bernardi L, Frontoni S, Pop-Busui R, et al. Cardiovascular autonomic neuropathy in diabetes: clinical impact, assessment, to investigate not only patients presenting with single, but also with multiple neuropathies. This will allow the identification of commonalities and differences in risk and protective factors of these diabetic complications. The study of haplotypes and gene interactions with lifestyle or environmental factors will lead to a better understanding of disease etiologies. The use of populations with a limited genetic pool, such as the Arab Bedouins, in which consanguineous marriages are common and family sizes are large, could also enhance our understanding of the heritability of T2DM and the diabetic neuropathies (292).

By highlighting the commonalties in genetic risk variants in the diabetic neuropathies, this review aims to stress the need of a unified genetic model for these diabetic complications. We cannot expect genetics alone to provide a full explanation for the cause and progression of the diabetic neuropathies, but research is continuing to support its important role in these multifactorial complications $(85,111,293-296)$. Ultimately, our understanding of the complex disease etiology of these diabetic neuropathies will require a multisystem multifactorial approach, combining genetics, epigenetics, proteomics, and treatment effects. A better disease process model would allow individualized preventative care and targeted drug delivery, and have a serious impact on improving patients' lives and reducing healthcare costs. The complexity of T2DM does not only lie in finding the missing puzzle pieces, but also in putting them together to see the 'big picture'.

\section{Author Contributions}

The idea for this review was conceived by $\mathrm{HJ}$ and further developed by all contributing authors. IW researched and wrote the manuscript. Expert advice and editing on the topic of diabetes-associated neuropathies was provided by HJ, AK, SL, and KK; HA provided advice and edited sections on the topic of genetics. All authors contributed to revising the final version of the manuscript for accuracy.

\section{Acknowledgments}

We gratefully acknowledge the support from Khalifa University. Funding for this work was provided by the Khalifa University Internal Research Fund (KUIRF) Level 2.

\section{Supplementary Material}

The Supplementary Material for this article can be found online at http://journal.frontiersin.org/article/10.3389/ fendo.2015.00088

diagnosis, and management. Diabetes Metab Res Rev (2011) 27(7):639-53 doi:10.1002/dmrr.1239

4. Wilson $\mathrm{N}$, Wright $\mathrm{D}$. Inflammatory mediators in diabetic neuropathy. J Diabetes (2011) S5:004. doi:10.4172/2155-6156.S5-004

5. Tesfaye S, Boulton AJM, Dyck PJ, Freeman R, Horowitz M, Kempler P, et al. Diabetic neuropathies: update on definitions, diagnostic criteria, estimation of severity, and treatments. Diabetes Care (2010) 33(10):2285-93. doi:10.2337/ dc10-1303

6. Vinik AI, Maser RE, Ziegler D. Neuropathy: the crystal ball for cardiovascular disease? Diabetes Care (2010) 33(7):1688-90. doi:10.2337/dc10-0745 
7. Fogarty DG, Rich SS, Hanna L, Warram JH, Krolewski AS. Urinary albumin excretion in families with type 2 diabetes is heritable and genetically correlated to blood pressure. Kidney Int (2000) 57(1):250-7. doi:10.1046/j.1523-1755.2000.00833.x

8. Wahlgren CM, Magnusson PK. Genetic influences on peripheral arterial disease in a twin population. Arterioscler Thromb Vasc Biol (2011) 31(3):678-82. doi:10.1161/ATVBAHA.110.210385

9. Ciccacci C, Di Fusco D, Cacciotti L, Morganti R, D’Amato C, Novelli G, et al. TCF7L2 gene polymorphisms and type 2 diabetes: association with diabetic retinopathy and cardiovascular autonomic neuropathy. Acta Diabetol (2013) 50(5):789-99. doi:10.1007/s00592-012-0418-x

10. Osztovits J, Horváth T, Littvay L, Steinbach R, Jermendy A, Tárnoki A, et al. Effects of genetic vs. environmental factors on cardiovascular autonomic function: a twin study. Diabet Med (2011) 28:1241-8. doi:10.1111/j.1464-5491.2011.03363.x

11. Basile KJ, Johnson ME, Xia Q, Grant SF. Genetic susceptibility to type 2 diabetes and obesity: follow-up of findings from genome-wide association studies. Int $J$ Endocrinol (2014) 2014:769671. doi:10.1155/2014/769671

12. Hindorff L, MacArthur J, Morales J, Junkins H, Hall P, Klemm A, et al. NHGRI GWAS Catalog [Internet] (2014). Available from: www.genome.gov/gwastudies

13. Dimitropoulos G, Tahrani AA, Stevens MJ. Cardiac autonomic neuropathy in patients with diabetes mellitus. World J Diabetes (2014) 5(1):17-39. doi:10.4239/ wjd.v5.i1.17

14. Aiello I, Serra G, Gilli P, Rosati G, Manca M, De Bastiani P, et al. Uremic neuropathy: correlations between electroneurographic parameters and serum levels of parathyroid hormone and aluminum. Eur Neurol (1982) 21:396-400. doi:10.1159/000115513

15. Kota S, Meher L, Jammula S, Modi K. Diabetic peripheral neuropathy-recent trends and future perspectives in management. Int J Clin Cases Investig (2012) 4(2):44-59.

16. Yadav S. Glycemic control in diabetic kidney disease patients. Clin Queries Nephrol (2012) 1(2):111-4. doi:10.1016/S2211-9477(12)70002-X

17. Krishnan AV, Kiernan MC. Uremic neuropathy: clinical features and new pathophysiological insights. Muscle Nerve (2007) 35(3):273-90. doi:10.1002/ mus. 20713

18. Brownlee M. Biochemistry and molecular cell biology of diabetic complications. Nature (2001) 414(6865):813-20. doi:10.1038/414813a

19. Brennan E, McEvoy C, Sadlier D, Godson C, Martin F. The genetics of diabetic nephropathy. Genes (Basel) (2013) 4(4):596-619. doi:10.3390/genes4040596

20. Chandy A, Pawar B, John M, Isaac R. Association between diabetic nephropathy and other diabetic microvascular and macrovascular complications. Saudi $J$ Kidney Dis Transpl (2008) 19(6):924-8.

21. Rocco M, Berns J. KDOQI clinical practice guideline for diabetes and CKD: 2012 update. Am J Kidney Dis (2012) 60:850-86. doi:10.1053/j.ajkd.2012.07.005

22. Bolton CF. Peripheral neuropathies associated with chronic renal failure. Can $J$ Neurol Sci (1980) 7:89-96.

23. Bolton C, Young G. Neurological Complications of Renal Disease. Boston, MA: Butterworths (1990). p. 1-256.

24. Kurata C, Uehara A, Sugi T, Ishikawa A, Fujita K, Yonemura K, et al. Cardiac autonomic neuropathy in patients with chronic renal failure on hemodialysis. Nephron (2000) 84:312-9. doi:10.1159/000045605

25. Baumgaertel MW, Kraemer M, Berlit P. Neurologic complications of acute and chronic renal disease. Handb Clin Neurol (2014) 119:383-93. doi:10.1016/ B978-0-7020-4086-3.00024-2

26. Tsiani E, Lekas P, Fantus IG, Dlugosz J, Whiteside C. High glucose-enhanced activation of mesangial cell p38 MAPK by ET-1, ANG II, and platelet-derived growth factor. Am J Physiol Endocrinol Metab (2002) 282(1):E161-9.

27. Brouns R, De Deyn PP. Neurological complications in renal failure: a review. Clin Neurol Neurosurg (2004) 107(1):1-16. doi:10.1016/j.clineuro.2004.07.012

28. Nielsen VK. Recovery from peripheral neuropathy after renal transplantation. Acta Neurol Scand (1970) 46(Suppl 43):207. doi:10.1111/j.1600-0404.1970. tb02190.x

29. Mitz M, Di Benedetto M, Klingbeil GE, Melvin JL, Piering W. Neuropathy in end-stage renal disease secondary to primary renal disease and diabetes. Arch Phys Med Rehabil (1984) 65:235-8.

30. Ho D, Rodig N, Kim H. Rapid reversal of uremic neuropathy following renal transplantation in an adolescent. Pediatr Transplant (2012) 16(7):1-7. doi:10.1111/j.1399-3046.2011.01630.x

31. Pirzada NA, Morgenlander JC. Peripheral neuropathy in patients with chronic renal failure. A treatable source of discomfort and disability. Postgrad Med (1997) 102:249-50.
32. Aggarwal H, Sood S, Jain D, Kaverappa V, Yadav S. Evaluation of spectrum of peripheral neuropathy in predialysis patients with chronic kidney disease. Ren Fail (2013) 35:1323-9. doi:10.3109/0886022X.2013.828261

33. Yosipovitch G, Yarnitsky D, Mermelstein V, Sprecher E, Reiss J, Witenberg C, et al. Paradoxical heat sensation in uremic polyneuropathy. Muscle Nerve (1995) 18:768-71. doi:10.1002/mus.880180714

34. Said G. Diabetic neuropathy - a review. Nat Clin Pract Neurol (2007) 3(6):331-40. doi:10.1038/ncpneuro0504

35. Strempska B, Bilinska M, Weyde W, Koszewicz M, Madziarska K, Golebiowski $\mathrm{T}$, et al. The effect of high-tone external muscle stimulation on symptoms and electrophysiological parameters of uremic peripheral neuropathy. Clin Nephrol (2013) 79(Suppl 1):S24-7. doi:10.5414/CNX77S103

36. Mallamaci F, Zoccali C, Ciccarelli M, Briggs JD. Autonomic function in uremic patients treated by hemodialysis or CAPD and in transplant patients. Clin Nephrol (1986) 25:175-80.

37. Jelinek $\mathrm{H}$, Khandoker A, Imam H. Pulse wave analysis using tone-entropy algorithm in people with and without foot complaints in rural diabetes screening clinic. Proceedings of the Eighth IASTED International Conference on Bioengineering. Innsbruck: International Association of Science and Technology for Development (IASTED) (2011). p. 249-53.

38. DiBona GF, Kopp UC. Neural control of renal function. Physiol Rev (1997) 77(1):75-197.

39. Savica V, Musolino R, Di Leo R, Santoro D, Vita G, Bellinghieri G. Autonomic dysfunction in uremia. Am J Kidney Dis (2001) 38(4 Suppl 1):118-21. doi:10.1053/ ajkd.2001.27418

40. Cornforth DJ, Tarvainen MP, Jelinek HF. Using renyi entropy to detect early cardiac autonomic neuropathy. Proceedings of the Annual International Conference of the IEEE Engineering in Medicine and Biology Society (EMBS), Osaka: IEEE (2013). p. 5562-5.

41. Muller IS, de Grauw WJC, van Gerwen WH, Bartelink ML, van Den Hoogen HJM, Rutten GE. Foot ulceration and lower limb amputation in type 2 diabetic patients in Dutch primary health care. Diabetes Care (2002) 25:570-4. doi:10.2337/diacare.25.3.570

42. Tesfaye S, Selvarajah D. Advances in the epidemiology, pathogenesis and management of diabetic peripheral neuropathy. Diabetes Metab Res Rev (2012) 28(Suppl 1):8-14. doi:10.1002/dmrr.2239

43. Bruun C, Siersma V, Guassora AD, Holstein P, de Fine Olivarius N. Amputations and foot ulcers in patients newly diagnosed with type 2 diabetes mellitus and observed for 19 years. The role of age, gender and co-morbidity. Diabet Med (2013) 30:964-72. doi:10.1111/dme.12196

44. Pscherer S, Dippel F-W, Lauterbach S, Kostev K. Amputation rate and risk factors in type 2 patients with diabetic foot syndrome under real-life conditions in Germany. Prim Care Diabetes (2012) 6(3):241-6. doi:10.1016/j.pcd.2012.02.004

45. Dixit S, Maiya A. Diabetic peripheral neuropathy and its evaluation in a clinical scenario: a review. J Postgrad Med (2014) 60(1):33. doi:10.4103/0022-3859.128805

46. Eaton S, Tesfaye S. Clinical manifestations and measurement of somatic neuropathy. Diabetes Rev (1999) 7:312-25.

47. Vinik A, Mehrabyan A. Diabetic neuropathies. Med Clin North Am (2004) 88(4):947-99. doi:10.1016/j.mcna.2004.04.009

48. Boulton A, Malik R. Diabetic somatic neuropathies. Diabetes Care (2004) 27(6):1458-80. doi:10.2337/diacare.27.6.1458

49. Tesfaye S, Chaturvedi N, Eaton SEM, Ward JD, Manes C, Ionescu-Tirgoviste C, et al. Vascular risk factors and diabetic neuropathy. $N$ Engl J Med (2005) 352:341-50. doi:10.1056/NEJMoa032782

50. VinikA, Maser R, Nakave A. Diabetic cardiovascular autonomicnerve dysfunction. US Endocr Dis (2007) 2:66-74. doi:10.1161/CIRCULATIONAHA.106.634949

51. Tarvainen MP, Cornforth DJ, Kuoppa P, Lipponen JA, Jelinek HF. Complexity of heart rate variability in type 2 diabetes - effect of hyperglycemia. Proceedings of the Annual International Conference of the IEEE Engineering in Medicine and Biology Society (EMBS), Osaka: IEEE (2013). p. 5558-61.

52. Maser RE, Lenhard MJ. Cardiovascular autonomic neuropathy due to diabetes mellitus: clinical manifestations, consequences, and treatment. JClin Endocrinol Metab (2005) 90(10):5896-903. doi:10.1210/jc.2005-0754

53. Pop-Busui R. Cardiac autonomic neuropathy in diabetes: a clinical perspective. Diabetes Care (2010) 33(2):434-41. doi:10.2337/dc09-1294

54. Gerritsen J, Dekker J, TenVoorde B, Kostense P, Heine R, Bouter L, et al. Impaired autonomic function is associated with increased mortality, especially in subjects with diabetes, hypertension, or a history of cardiovascular disease the Hoorn study. Diabetes Care (2001) 24(10):1793-8. doi:10.2337/diacare.24.10.1793 
55. Valensi P, Pariès J, Attali JR. Cardiac autonomic neuropathy in diabetic patients: influence of diabetes duration, obesity, and microangiopathic complications the French multicenter study. Metabolism (2003) 52(7):815-20. doi:10.1016/ S0026-0495(03)00095-7

56. Voulgari C, Psallas M, Kokkinos A, Argiana V, Katsilamabros N, Tentolouris $\mathrm{N}$. The association between cardiac autonomic neuropathy with metabolic and other factors in subjects with type 1 and type 2 diabetes. J Diabetes Complications (2011) 25(3):159-67. doi:10.1016/j.jdiacomp.2010.06.001

57. Viswanathan V, Prasad D, Chamukuttan S, Ramachandran A. High prevalence and early onset of cardiac autonomic neuropathy among South Indian type 2 diabetic patients with nephropathy. Diabetes Res Clin Pract (2000) 48:211-6. doi:10.1016/S0168-8227(00)00127-3

58. Moțățăianu A, Bălaşa R, Voidăzan S, Bajkó Z. Cardiovascular autonomic neuropathy in context of other complications of type 2 diabetes mellitus. Biomed Res Int (2013) 2013:507216. doi:10.1155/2013/507216

59. Wu J-S, Yang Y-C, Lin T-S, Huang Y-H, Chen J-J, Lu F-H, et al. Epidemiological evidence of altered cardiac autonomic function in subjects with impaired glucose tolerance but not isolated impaired fasting glucose. J Clin Endocrinol Metab (2007) 92:3885-9. doi:10.1210/jc.2006-2175

60. Pfeifer M, Weinberg CR, Cook DL, Reenan A, Halter JB, Ensinck JW, et al. Autonomic neural dysfunction in recently diagnosed diabetic subjects. Diabetes Care (1984) 7(5):447-53. doi:10.2337/diacare.7.5.447

61. Wiggin TD, Sullivan KA, Pop-busui R, Amato A, Sima AAF, Feldman EL. Elevated triglycerides correlate with progression of diabetic neuropathy. Diabetes (2009) 58:1634-40. doi:10.2337/db08-1771

62. Stratton IM, Adler AI, Neil HAW, Matthews DR, Manley SE, Cull CA, et al. Association of glycaemia with macrovascular and prospective observational study. BMJ Clin Res (2000) 321(7258):405-12. doi:10.1136/bmj.321.7258.405

63. Kuehl M, Stevens MJ. Cardiovascular autonomic neuropathies as complications of diabetes mellitus. Nat Rev Endocrinol (2012) 8(7):405-16. doi:10.1038/ nrendo.2012.21

64. Felício JS, Santos FM, de Souza ACC, Felício KM, Ribeiro AB, Zanella MT. Autonomic neuropathy tests correlate with left ventricular mass and cardiac diastolic function in normotensive patients with type 2 diabetes mellitus and without left ventricular hypertrophy. Exp Clin Cardiol (2010) 15(1):e5-9.

65. Jelinek H, Md Imam H, Al-Aubaidy H, Khandoker A. Association of cardiovascular risk using non-linear heart rate variability measures with the Framingham risk score in a rural population. Front Physiol (2013) 4:186. doi:10.3389/ fphys.2013.00186

66. Stranieri A, Abawajy J, Kelarev A, Huda S, Chowdhury M, Jelinek HF. An approach for Ewing test selection to support the clinical assessment of cardiac autonomic neuropathy. ArtifIntell Med (2013) 58:185-93. doi:10.1016/j.artmed.2013.04.007

67. Abawajy J, Chowdhury M, Kelarev A, Jelinek H. Enhancing predictive accuracy of cardiac autonomic neuropathy using blood biochemistry features and iterative multi-tier ensembles. IEEE J Biomed Health Inform (2014) 11(4). doi:10.1109/ JBHI.2014.2363177

68. Pinto A, Tuttolomondo A, Di Raimondo D, La Placa S, Di Sciacca R, Fernandez P, et al. Ischemic stroke in patients with diabetic foot. Int Angiol (2007) 26(3):266-9.

69. Pinto A, Tuttolomondo A, Di Raimondo D, Fernandez P, La Placa S, Di Gati M, et al. Cardiovascular risk profile and morbidity in subjects affected by type 2 diabetes mellitus with and without diabetic foot. Metabolism (2008) 57(5):676-82. doi:10.1016/j.metabol.2008.01.004

70. Weizmann Institute of Science . Uremic Neuropathy [Internet]. MalaCards (2014). Available from: http://www.malacards.org/card/uremic_neuropathy? search=uremic+neuropathy

71. Liabeuf S, Lenglet A, Desjardins L, Neirynck N, Glorieux G, Lemke H-D, et al. Plasma beta-2 microglobulin is associated with cardiovascular disease in uremic patients. Kidney Int (2012) 82(12):1297-303. doi:10.1038/ki.2012.301

72. Canaud B, Morena M, Cristol J, Krieter D. Beta2-microglobulin, a uremic toxin with a double meaning. Kidney Int (2006) 69:1297-9. doi:10.1038/sj.ki.5000389

73. Duranton F, Cohen G, De Smet R, Rodriguez M, Jankowski J, Vanholder R, et al. Normal and pathologic concentrations of uremic toxins. J Am Soc Nephrol (2012) 23(7):1258-70. doi:10.1681/ASN.2011121175

74. Vedralová M, Kotrbova-Kozak A, Zelezníková V, Zoubková H, Rychlík I, Cerná $\mathrm{M}$. Polymorphisms in the vitamin D receptor gene and parathyroid hormone gene in the development and progression of diabetes mellitus and its chronic complications, diabetic nephropathy and non-diabetic renal disease. Kidney Blood Press Res (2012) 36(1):1-9. doi:10.1159/000339021
75. Reheem RNAMA, Fattah MAHMA. Serum vitamin D and parathormone (PTH) concentrations as predictors of the development and severity of diabetic retinopathy. Alexandria J Med (2013) 49(2):119-23. doi:10.1016/j.ajme.2012.08.006

76. Suzuki A, Kotake M, Ono Y, Kato T, Oda N, Hayakawa N, et al. Hypovitaminosis D in type 2 diabetes mellitus: association with microvascular complications and type of treatment. Endocr J (2006) 53(4):503-10. doi:10.1507/endocrj.K06-001

77. Avram MM, Feinfeld DA, Huatuco AH. Search for the uremic toxin. Decreased motor-nerve conduction velocity and elevated parathyroid hormone in uremia. N Engl J Med (1978) 298:1000-3. doi:10.1056/NEJM197805042981805

78. Rodriguez M, Lorenzo V. Parathyroid hormone, a uremic toxin. Semin Dial (2009) 22:363-8. doi:10.1111/j.1525-139X.2009.00581.x

79. Vita G, Savica V, Calabrò R, Padovano I, Manna L, Toscano A, et al. Uremic vagal neuropathy: has parathyroid hormone a pathogenetic role? Funct Neurol (1986) 1(3):253-9.

80. Maeda S, Osawa N, Hayashi T, Tsukada S, Kobayashi M, Kikkawa R. Genetic variations associated with diabetic nephropathy and type II diabetes in a Japanese population. Kidney Int Suppl (2007) 106:S43-8. doi:10.1038/sj.ki.5002385

81. McDonough C, Palmer N, Hicks P. A genome wide association study for diabetic nephropathy genes in African Americans. Kidney Int (2010) 79(5):563-72. doi:10.1038/ki.2010.467

82. Maeda S. Genome-wide search for susceptibility gene to diabetic nephropathy by gene-based SNP. Diabetes Res Clin Pract (2004) 66(Suppl 1):S45-7. doi:10.1016/j. diabres.2003.09.017

83. Maeda S, Kobayashi M, Araki S, Babazono T, Freedman BI, Bostrom MA, et al. A single nucleotide polymorphism within the acetyl-coenzyme A carboxylase beta gene is associated with proteinuria in patients with type 2 diabetes. PLoS Genet (2010) 6(2):e1000842. doi:10.1371/journal.pgen.1000842

84. Canani LH, Costa LA, Crispim D, Goncalves Dos Santos K, Roisenberg I, Lisboa HR, et al. The presence of allele D of angiotensin-converting enzyme polymorphism is associated with diabetic nephropathy in patients with less than 10 years duration of type 2 diabetes. Diabet Med (2005) 22:1167-72. doi:10.1111/j.1464-5491.2005.01622.x

85. Blech I, Katzenellenbogen M, Katzenellenbogen A, Wainstein J, Rubinstein A, Harman-Boehm I, et al. Predicting diabetic nephropathy using a multifactorial genetic model. PLoS One (2011) 6(4):e18743. doi:10.1371/journal.pone.0018743

86. Osawa N, Koya D, Araki S, Uzu T, Tsunoda T, Kashiwagi A, et al. Combinational effect of genes for the renin-angiotensin system in conferring susceptibility to diabetic nephropathy. J Hum Genet (2007) 52:143-51. doi:10.1007/ s10038-006-0090-5

87. Neamat-Allah M, Feeney SA, Savage DA, Maxwell AP, Hanson RL, Knowler WC, et al. Analysis of the association between diabetic nephropathy and polymorphisms in the aldose reductase gene in type 1 and type 2 diabetes mellitus. Diabet Med (2001) 18(11):906-14. doi:10.1046/j.0742-3071.2001.00598.x

88. Ng MC, Baum L, So W-Y, Lam VKL, Wang Y, Poon E, et al. Association of lipoprotein lipase S447X, apolipoprotein E exon 4, and apoC3 -455T>C polymorphisms on the susceptibility to diabetic nephropathy. Clin Genet (2006) 70(1):20-8. doi:10.1111/j.1399-0004.2006.00628.x

89. Nakajima K, Tanaka Y, Nomiyama T, Ogihara T, Ikeda F, Kanno R, et al. RANTES promoter genotype is associated with diabetic nephropathy in type 2 diabetic subjects. Diabetes Care (2003) 26(3):892-8. doi:10.2337/diacare.26.3.892

90. Mokubo A, Tanaka Y, Nakajima K, Watada H, Hirose T, Kawasumi M, et al. Chemotactic cytokine receptor 5 (CCR5) gene promoter polymorphism $(59029 \mathrm{~A} / \mathrm{G})$ is associated with diabetic nephropathy in Japanese patients with type 2 diabetes: a 10-year longitudinal study. Diabetes Res Clin Pract (2006) 73:89-94. doi:10.1016/j.diabres.2005.12.006

91. Janssen B, Hohenadel D, Brinkkoetter P, Peters V, Rind N, Fischer C, et al. Carnosine as a protective factor in diabetic nephropathy: association with a leucine repeat of the carnosinase gene CNDP1. Diabetes (2005) 54:2320-7. doi:10.2337/diabetes.54.8.2320

92. Santos KG, Canani LH, Gross JL, Tschiedel B, Souto KE, Roisenberg I. Relationship of p22phox C242T polymorphism with nephropathy in type 2 diabetic patients. J Nephrol (2005) 18:733-8.

93. Shimazaki A, Kawamura Y, Kanazawa A, Sekine A, Saito S, Tsunoda T, et al. Genetic variations in the gene encoding ELMO1 are associated with susceptibility to diabetic nephropathy. Diabetes (2005) 54:1171-8. doi:10.2337/ diabetes.54.4.1171

94. Canani LH, Capp C, Ng DPK, Choo SGL, Maia AL, Nabinger GB, et al. The fatty acid-binding protein-2 A54T polymorphism is associated with renal disease 
in patients with type 2 diabetes. Diabetes (2005) 54:3326-30. doi:10.2337/ diabetes.54.11.3326

95. Palmer N, Freedman B. Diabetic nephropathy: FRMD3 in diabetic nephropathyguilt by association. Nat Rev Nephrol (2013) 9:313-4. doi:10.1038/nrneph.2013.81

96. Ng DPK, Nurbaya S, Ye SHJ, Krolewski AS. An IL-6 haplotype on human chromosome $7 \mathrm{p} 21$ confers risk for impaired renal function in type 2 diabetic patients. Kidney Int (2008) 74:521-7. doi:10.1038/ki.2008.202

97. Ohshige T, Tanaka Y, Araki S, Babazono T, Toyoda M, Umezono T, et al. A single nucleotide polymorphism in KCNQ1 is associated with susceptibility to diabetic nephropathy in Japanese subjects with type 2 diabetes. Diabetes Care (2010) 33(4):842-6. doi:10.2337/dc09-1933

98. Maeda S, Haneda M, Guo B, Koya D, Hayashi K, Sugimoto T, et al. Dinucleotide repeat polymorphism of matrix metalloproteinase- 9 gene is associated with diabetic nephropathy. Kidney Int (2001) 60:1428-34. doi:10.1046/j.1523-1755.2001.00945.x

99. Yang S, Zhang J, Feng C, Huang G. MTHFR 677T variant contributes to diabetic nephropathy risk in Caucasian individuals with type 2 diabetes: a meta-analysis. Metabolism (2013) 62(4):586-94. doi:10.1016/j.metabol.2012.10.004

100. Freedman BI, Hicks PJ, Bostrom MA, Comeau ME, Divers J, Bleyer AJ, et al. Nonmuscle myosin heavy chain 9 gene MYH9 associations in African Americans with clinically diagnosed type 2 diabetes mellitus-associated ESRD. Nephrol Dial Transplant (2009) 24:3366-71. doi:10.1093/ndt/gfp316

101. Kamiyama M, Kobayashi M, Araki SI, Iida A, Tsunoda T, Kawai K, et al. Polymorphisms in the 3' UTR in the neurocalcin delta gene affect mRNA stability, and confer susceptibility to diabetic nephropathy. Hum Genet (2007) 122:397-407. doi:10.1007/s00439-007-0414-3

102. Caramori ML, Canani LH, Costa LA, Gross JL. The human peroxisome proliferator-activated receptor gamma2 (PPARgamma2) Pro12Ala polymorphism is associated with decreased risk of diabetic nephropathy in patients with type 2 diabetes. Diabetes (2003) 52:3010-3. doi:10.2337/diabetes.52.12.3010

103. Hanson RL, Craig DW, Millis MP, Yeatts KA, Kobes S, Pearson JV, et al. Identification of PVT1 as a candidate gene for end-stage renal disease in type 2 diabetes using a pooling-based genome-wide single nucleotide polymorphism association study. Diabetes (2007) 56:975-83. doi:10.2337/db06-1072

104. Maeda S, Koya D, Araki S, Babazono T, Umezono T, Toyoda M, et al. Association between single nucleotide polymorphisms within genes encoding sirtuin families and diabetic nephropathy in Japanese subjects with type 2 diabetes. Clin Exp Nephrol (2011) 15:381-90. doi:10.1007/s10157-011-0418-0

105. Tanaka N, Babazono T, Saito S, Sekine A, Tsunoda T, Haneda M, et al. Association of solute carrier family 12 (sodium/chloride) member 3 with diabetic nephropathy, identified by genome-wide analyses of single nucleotide polymorphisms. Diabetes (2003) 52:2848-53. doi:10.2337/diabetes.52.11.2848

106. Sun L, Yuan Q, Cao N, Guo W, Yao L, Feng J, et al. VEGF genetic polymorphisms may contribute to the risk of diabetic nephropathy in patients with diabetes mellitus: a meta-analysis. Scientific WorldJournal (2014) 2014:624573. doi:10.1155/2014/624573

107. Maeda S, Araki S-I, Babazono T, Toyoda M, Umezono T, Kawai K, et al. Replication study for the association between four loci identified by a genomewide association study on European American subjects with type 1 diabetes and susceptibility to diabetic nephropathy in Japanese subjects with type 2 diabetes. Diabetes (2010) 59(8):2075-9. doi:10.2337/db10-0067

108. Woroniecka KI, Park ASD, Mohtat D, Thomas DB, Pullman JM, Susztak K. Transcriptome analysis of human diabetic kidney disease. Diabetes (2011) 60:2354-69. doi:10.2337/db10-1181

109. Brennan EP, Morine MJ, Walsh DW, Roxburgh SA, Lindenmeyer MT, Brazil DP, et al. Next-generation sequencing identifies TGF- $\beta 1$-associated gene expression profiles in renal epithelial cells reiterated in human diabetic nephropathy. Biochim Biophys Acta (2012) 1822:589-99. doi:10.1016/j.bbadis.2012.01.008

110. Schmid H, Boucherot A, Yasuda Y, Henger A, Brunner B, Eichinger F, et al. Modular activation of nuclear factor-kappaB transcriptional programs in human diabetic nephropathy. Diabetes (2006) 55:2993-3003. doi:10.2337/db06-0477

111. Tang Z-H, Fang Z, Zhou L. Human genetics of diabetic vascular complications. J Genet (2013) 92(3):677-94. doi:10.1007/s12041-013-0288-1

112. Pezzolesi MG, Krolewski AS. The genetic risk of kidney disease in type 2 diabetes. Med Clin North Am (2013) 97(1):91-107. doi:10.1016/j.mcna.2012.10.005

113. Carpena M, Rados D, Sortica D, de Souza B, Reis A, Canani L, et al. Genetics of diabetic nephropathy. Arq Bras Endocrinol Metabol (2010) 54(3):253-61. doi:10.1590/S0004-27302010000300002
114. Li Y, Tong N. Angiotensin-converting enzyme I/D polymorphism and diabetic peripheral neuropathy in type 2 diabetes mellitus: a meta-analysis. J Renin Angiotensin Aldosterone Syst (2014). doi:10.1177/1470320314539828

115. Sivenius K, Pihlajamäki J. Aldose reductase gene polymorphisms and peripheral nerve function in patients with type 2 diabetes. Diabetes Care (2004) 27(8):2021-6. doi:10.2337/diacare.27.8.2021

116. Papanas N, Papatheodorou K, Papazoglou D, Kotsiou S, Christakidis D, Maltezos E. An insertion/deletion polymorphism in the alpha2B adrenoceptor gene is associated with peripheral neuropathy in patients with type 2 diabetes mellitus. Exp Clin Endocrinol Diabetes (2007) 115:327-30. doi:10.1055/s-2007-967084

117. Tsuzuki S, Murano T, Watanabe H, Itoh Y, Miyashita Y, Shirai K. The examination of apoE phenotypes in diabetic patients with peripheral neuropathy. Rinsho Byori (1998) 46:829-33.

118. Bedlack RS, Edelman D, Gibbs JW, Kelling D, Strittmatter W, Saunders AM, et al. APOE genotype is a risk factor for neuropathy severity in diabetic patients. Neurology (2003) 60:1022-4. doi:10.1212/01.WNL.0000056689.50682.94

119. Monastiriotis C, Papanas N, Veletza S, Maltezos E. APOE gene polymorphisms and diabetic peripheral neuropathy. Arch Med Sci (2012) 8(4):583-8. doi:10.5114/ aoms.2012.30279

120. Tang T, Prior S, Li K, Ireland H, Bain S, Hurel S, et al. Association between the rs 1050450 glutathione peroxidase-1 $(\mathrm{C}>\mathrm{T})$ gene variant and peripheral neuropathy in two independent samples of subjects with diabetes mellitus. Nutr Metab Cardiovasc Dis (2012) 22(5):417-25. doi:10.1016/j.numecd.2010.08.001

121. Basol N, Inanir A, Yigit S, Karakus N, Kaya SU. High association of IL-4 gene intron 3 VNTR polymorphism with diabetic peripheral neuropathy. J Mol Neurosci (2013) 51(2):437-41. doi:10.1007/s12031-013-0048-y

122. Kolla VK, Madhavi G, Pulla Reddy B, Srikanth Babu BM, Yashovanthi J, Valluri VL, et al. Association of tumor necrosis factor alpha, interferon gamma and interleukin 10 gene polymorphisms with peripheral neuropathy in South Indian patients with type 2 diabetes. Cytokine (2009) 47(3):173-7. doi:10.1016/j. cyto.2009.06.007

123. Yigit S, Karakus N, Inanir A. Association of MTHFR gene C677T mutation with diabetic peripheral neuropathy and diabetic retinopathy. Mol Vis (2013) 19:1626-30.

124. Margolis DJ, Gupta J, Thom SR, Fischer M, Schelling JR, Mitra N. Diabetes, lower extremity amputation, loss of protective sensation, and NOS1AP in the CRIC study. Wound Repair Regen (2014) 21(1):17-24. doi:10.1111/j.1524-475X.2012.00866.x

125. Shah VN. Endothelial nitric oxide synthase gene polymorphism and the risk of diabetic neuropathy in asian indian patients with type 2 diabetes. J Diabetes Metab (2013) 4(2):243. doi:10.4172/2155-6156.1000243

126. Manea S-A, Robciuc A, Guja C, Heltianu C. Identification of gene variants in NOS3, ET-1 and RAS that confer risk and protection against microangiopathy in type 2 diabetic obese subjects. Biochem Biophys Res Commun (2011) 407(3):486-90. doi:10.1016/j.bbrc.2011.03.043

127. Mehrab-Mohseni M, Tabatabaei-Malazy O, Hasani-Ranjbar S, Amiri P, Kouroshnia A, Bazzaz JT, et al. Endothelial nitric oxide synthase VNTR (intron $4 \mathrm{a} / \mathrm{b}$ ) polymorphism association with type 2 diabetes and its chronic complications. Diabetes Res Clin Pract (2011) 91(3):348-52. doi:10.1016/j. diabres.2010.12.030

128. Rudofsky G, Reismann P, Witte S. Asp299Gly and Thr399Ile genotypes of the TLR4 gene are associated with a reduced prevalence of diabetic neuropathy in patients with type 2 diabetes. Diabetes Care (2004) 27(1):179-83. doi:10.2337/ diacare.27.1.179

129. Yamasaki H, Sasaki H, Ogawa K. Uncoupling protein 2 promoter polymorphism $-866 \mathrm{G} / \mathrm{A}$ affects peripheral nerve dysfunction in Japanese type 2 diabetic patients. Diabetes Care (2006) 29(4):888-94. doi:10.2337/diacare.29.04.06.dc05-1984

130. Stoian A, Bacârea A, Moțățăianu A, Stoian M, Gliga F, Bacârea V, et al. Vascular endothelial growth factor insertion/deletion gene polymorphism in patients with type 2 diabetes and diabetic peripheral polyneuropathy. Rom Rev Lab Med (2014) 22(2):165-72. doi:10.2478/rrlm-2014-0023

131. Elango S, Venugopal S, Thangaraj K, Viswanadha VP. Novel mutations in ATPase 8 , ND1 and ND5 genes associated with peripheral neuropathy of diabetes. Diabetes Res Clin Pract (2014) 103(3):e49-52. doi:10.1016/j.diabres.2013.12.015

132. Parson HK, Winchester MW, Neumann SA, Vinik AI. Choline transporter gene variation is associated with diabetes and autonomic neuropathy in African Americans. Diabetes (2011) 60(Suppl 1):A565-6.

133. Nikolic VN, Jevtovic-Stoimenov T, Stokanovic D, Milovanovic M, VelickovicRadovanovic R, Pesic S, et al. An inverse correlation between TNF alpha serum 
levels and heart rate variability in patients with heart failure. J Cardiol (2013) 62(1):37-43. doi:10.1016/j.jjcc.2013.02.013

134. Due-Andersen R, Høi-Hansen T, Olsen NV, Larroude CE, Kanters JK, Boomsma $\mathrm{F}$, et al. Cardiac repolarization during hypoglycaemia and hypoxaemia in healthy males: impact of renin-angiotensin system activity. Europace (2008) 10(2):219-26. doi:10.1093/europace/eum286

135. Matsunaga T, Yasuda K, Adachi T, Gu N, Yamamura T, Moritani T, et al. Association of beta-adrenoceptor polymorphisms with cardiac autonomic modulation in Japanese males. Am Heart J (2007) 154(4):759-66. doi:10.1016/j. ahj.2007.03.053

136. Thamotharampillai K, Chan AKF, Bennetts B, Craig ME, Cusumano J, Silink $\mathrm{M}$, et al. Decline in neurophysiological function after 7 years in an adolescent diabetic cohort and the role of aldose reductase gene polymorphisms. Diabetes Care (2006) 29(9):2053-7. doi:10.2337/dc06-0678

137. Vasquez E, Peotta V, Meyrelles S. Cardiovascular autonomic imbalance and baroreflex dysfunction in the apolipoprotein E-deficient mouse. Cell Physiol Biochem (2012) 29(5-6):635-46. doi:10.1159/000277623

138. Chistiakov DA, Zotova EV, Savostanov KV, Bursa TR, Galeev IV, Strokov IA, et al. The $262 \mathrm{~T}>\mathrm{C}$ promoter polymorphism of the catalase gene is associated with diabetic neuropathy in type 1 diabetic Russian patients. Diabetes Metab (2006) 32(1):63-8. doi:10.1016/S1262-3636(07)70248-3

139. Yasuda K, Matsunaga T, Moritani T, Nishikino M, Gu N, Yoshinaga M, et al. T393C polymorphism of GNAS1 associated with the autonomic nervous system in young, healthy Japanese subjects. Clin Exp Pharmacol Physiol (2004) 31:597-601. doi:10.1111/j.1440-1681.2004.04059.x

140. Baccarelli A, Cassano P, Litonjua A, Park S. Cardiac autonomic dysfunction effects from particulate air pollution and protection by dietary methyl nutrients and metabolic polymorphisms. Circulation (2008) 117(14):1802-9. doi:10.1161/ CIRCULATIONAHA.107.726067

141. Lorenzo O, Picatoste B, Ares-Carrasco S, Ramírez E, Egido J, Tunóńn J. Potential role of nuclear factor $\mathbf{\kappa} B$ in diabetic cardiomyopathy. Mediators Inflamm (2011) 2011:652097. doi:10.1155/2011/652097

142. Chowdhary S, Vaile JC, Fletcher J, Ross HF, Coote JH, Townend JN. Nitric oxide and cardiac autonomic control in humans. Hypertension (2000) 36(2):264-9. doi:10.1161/01.HYP.36.2.264

143. Binkley PF, Nunziatta E, Liu-Stratton Y, Cooke G. A polymorphism of the endothelial nitric oxide synthase promoter is associated with an increase in autonomic imbalance in patients with congestive heart failure. Am Heart J (2005) 149(2):342-8. doi:10.1016/j.ahj.2004.05.059

144. Okun E, Griffioen KJ, Rothman S, Wan R, Cong W-N, De Cabo R, et al. Toll-like receptors 2 and 4 modulate autonomic control of heart rate and energy metabolism. Brain Behav Immun (2014) 36:90-100. doi:10.1016/j.bbi.2013.10.013

145. Park H-J, Zhang Y, Du C, Welzig M, Madias C, Aronovitz MJ, et al. Role of SREBP-1 in the Development of Parasympathetic Dysfunction in the Hearts of Type I Diabetic Akita Mice. Circ Res (2009) 105(3):287-94. doi:10.1161/ CIRCRESAHA.109.193995

146. Jung C-H, Kim B-Y, Kim C-H, Kang S-K, Jung S-H, Mok J-O. Association of serum adipocytokine levels with cardiac autonomic neuropathy in type 2 diabetic patients. Cardiovasc Diabetol (2012) 11(1):24. doi:10.1186/1475-2840-11-24

147. Shinohara T, Takahashi N, Yufu K, Anan F, Kakuma T, Hara M, et al. Role of interleukin-6 levels in cardiovascular autonomic dysfunction in type 2 diabetic patients. Eur J Nucl Med Mol Imaging (2008) 35(9):1616-23. doi:10.1007/ s00259-008-0809-y

148. Lieb DC, Parson HK, Mamikunian G, Vinik AI. Cardiac autonomic imbalance in newly diagnosed and established diabetes is associated with markers of adipose tissue inflammation. Exp Diabetes Res (2012) 2012:878760. doi:10.1155/2012/878760

149. Busjahn A, Voss A, Knoblauch H, Knoblauch M, Jeschke E, Wessel N, et al. Angiotensinogen gene polymorphisms and heart rate variability in twins. Am J Cardiol (1998) 81(6):755-60. doi:10.1016/S0002-9149(97)01019-9

150. Ng E, Lu Y, Hambly B, Jelinek HF, Yu B, Matthews S, et al. Angiotensin-converting enzyme gene DD genotype is associated with increased systolic blood pressure in an Australian rural type 2 diabetic cohort. Hypertens Res (2013) 36(4):381-2. doi:10.1038/hr.2012.195

151. Steeds RP, Fletcher J, Parry H, Chowdhary S, Channer KS, West J, et al. The angiotensin-converting enzyme gene $\mathrm{I} / \mathrm{D}$ polymorphism and heart rate variability following acute myocardial infarction. Clin Auton Res (2002) 12(2):66-71. doi:10.1007/s102860200022
152. Forbes JM, Cooper ME. Mechanisms of diabetic complications. Physiol Rev (2013) 93(1):137-88. doi:10.1152/physrev.00045.2011

153. Crisan D, Carr J. Angiotensin I-converting enzyme. J Mol Diagn (2000) 2(3):105-15. doi:10.1016/S1525-1578(10)60624-1

154. Dhar S, Ray S, Dutta A, Sengupta B, Chakrabarti S. Polymorphism of ACE gene as the genetic predisposition of coronary artery disease in Eastern India. Indian Heart J (2012) 64:576-81. doi:10.1016/j.ihj.2012.08.005

155. Tiret L, Blanc H, Ruidavets J, Arveiler D, Luc G, Jeunemaitre X, et al. Gene polymorphisms of the renin-angiotensin system in relation to hypertension and parental history of myocardial infarction and stroke: the PEGASE study. Projet d'Etude des Gènes de l'Hypertension Artérielle Sévère à modérée Essentielle. J Hypertens (1998) 16(1):37-44. doi:10.1097/00004872-199816010-00007

156. Seshiah PN. Angiotensin II stimulation of NAD $(\mathrm{P}) \mathrm{H}$ oxidase activity: upstream mediators. Circ Res (2002) 91(5):406-13. doi:10.1161/01. RES.0000033523.08033.16

157. Nickenig G. Central role of the AT(1)-receptor in atherosclerosis. J Hum Hypertens (2002) 16(Suppl 3):S26-33. doi:10.1038/sj.jhh.1001436

158. Zhou Y-F, Yan H, Hou X-P, Miao J-L, Zhang J, Yin Q-X, et al. Association study of angiotensin converting enzyme gene polymorphism with elderly diabetic hypertension and lipids levels. Lipids Health Dis (2013) 12(1):187. doi:10.1186/1476-511X-12-187

159. Purnamasari D, Widjojo BD, Antono D, Syampurnawati M. ACE gene polymorphism and atherosclerotic lesion of carotid artery among offsprings of type 2 diabetes mellitus. Acta Med Indones (2012) 44:128-34.

160. Degirmenci I, Kebapci N, Basaran A, Efe B, Gunes HV, Akalin A, et al. Frequency of angiotensin-converting enzyme gene polymorphism in Turkish type 2 diabetic patients. Int J Clin Pract (2005) 59:1137-42. doi:10.1111/j.1368-5031.2005.00586.x

161. Rigat B, Hubert C, Alhenc-Gelas F, Cambien F, Corvol P, Soubrier F. An insertion/ deletion polymorphism in the angiotensin I-converting enzyme gene accounting for half the variance of serum enzyme levels. J Clin Invest (1990) 86:1343-6. doi:10.1172/JCI114844

162. Johnston CI. Tissue angiotensin converting enzyme in cardiac and vascular hypertrophy, repair, and remodeling [clinical conference]. Hypertension (1994) 23(2):258-68. doi:10.1161/01.HYP.23.2.258

163. Zintzaras E, Zdoukopoulos N. A field synopsis and meta-analysis of genetic association studies in peripheral arterial disease: the CUMAGAS-PAD database. Am J Epidemiol (2009) 170(1):1-11. doi:10.1093/aje/kwp094

164. Cooper ME. The role of the renin-angiotensin-aldosterone system in diabetes and its vascular complications. Am J Hypertens (2004) 17(11 Pt 2):16S-20S. doi:10.1016/j.amjhyper.2004.08.004

165. Chawla T, Sharma D, Singh A. Role of the renin angiotensin system in diabetic nephropathy. World J Diabetes (2010) 1:141-5. doi:10.4239/wjd.v1.i5.141

166. Rahimi Z. ACE insertion/deletion (I/D) polymorphism and diabetic nephropathy. J Nephropathol (2012) 1(3):143-51. doi:10.5812/nephropathol.8109

167. Wang H, Fan D, Zhang Y. Angiogenin gene polymorphism - a risk factor for diabetic peripheral neuropathy in the northern Chinese Han population? Neural Regen Res (2013) 8(36):3434-40. doi:10.3969/j.issn.1673-5374.2013.36.009

168. Mooyaart AL, Valk EJ, Van Es LA, Bruijn JA, De Heer E, Freedman BI, et al. Genetic associations in diabetic nephropathy: a meta-analysis. Diabetologia (2011) 54:544-53. doi:10.1007/s00125-010-1996-1

169. Mansoor Q, Javaid A, Bilal N, Ismail M. Angiotensin-converting enzyme (ACE) gene II genotype protects against the development of diabetic peripheral neuropathy in type 2 diabetes mellitus. J Diabetes (2012) 4(3):257-61. doi:10.1111/j.1753-0407.2012.00205.x

170. Yu Z-Y, Chen L-S, Zhang L-C, Zhou T-B. Meta-analysis of the relationship between ACE I/D gene polymorphism and end-stage renal disease in patients with diabetic nephropathy. Nephrology (Carlton) (2012) 17(5):480-7. doi:10.1111/j.1440-1797.2012.01592.x

171. Krajina-Andricević M, Zibar L, Glavas-Obrovac L, Stefanić M, Avdicević M, BarbićJ. [Angiotensin-converting enyme insertion/deletion polymorphism and blood pressure regulation in type 2 diabetic patients]. Acta Med Croatica (2011) 65(Suppl 3):14-9.

172. Wetmore JB, Johansen KL, Sen S, Hung AM, Lovett DH. An angiotensin converting enzyme haplotype predicts survival in patients with end stage renal disease. Hum Genet (2006) 120:201-10. doi:10.1007/s00439-006-0191-4

173. Czupryniak L, Młynarski W, Pawłowski M, Saryusz-Wolska M, Borkowska A, Klich I, et al. Circadian blood pressure variation in normotensive type 2 diabetes 
patients and angiotensin converting enzyme polymorphism. Diabetes Res Clin Pract (2008) 80:386-91. doi:10.1016/j.diabres.2008.01.007

174. Zhu X, Chang YP, Yan D, Weder A, Cooper R, Luke A, et al. Associations between hypertension and genes in the renin-angiotensin system. Hypertension (2003) 41:1027-34. doi:10.1161/01.HYP.0000068681.69874.СB

175. Wang B, Wang F, Zhang Y, Zhao S, Zhao W, Yan S, et al. Effects of RAS inhibitors on diabetic retinopathy: a systematic review and meta-analysis. Lancet Diabetes Endocrinol (2015) 3(4):263-74. doi:10.1016/S2213-8587(14)70256-6

176. Ha S. ACE insertion/deletion polymorphism and diabetic nephropathy: clinical implications of genetic information. J Diabetes Res (2014) 2014:846068. doi:10.1155/2014/846068

177. Malik RA, Williamson S, Abbott C, Carrington AL, Iqbal J, Schady W, et al. Effect of angiotensin-converting-enzyme (ACE) inhibitor trandolapril on human diabetic neuropathy: randomised double-blind controlled trial. Lancet (1998) 352(9145):1978-81. doi:10.1016/S0140-6736(98)02478-7

178. Boulton AJ, Vinik AI, Arezzo JC, Bril V, Feldman EL, Freeman R, et al. Diabetic neuropathies: a statement by the American Diabetes Association. Diabetes Care (2005) 28(4):956-62. doi:10.2337/diacare.28.4.956

179. Didangelos TP, Arsos GA, Karamitsos DT, Athyros VG, Georga SD, Karatzas ND. Effect of quinapril or losartan alone and in combination on left ventricular systolic and diastolic functions in asymptomatic patients with diabetic autonomic neuropathy. J Diabetes Complications (2006) 20(1):1-7. doi:10.1016/j. jdiacomp.2005.05.002

180. Athyros VG, Didangelos TP, Karamitsos DT, Papageorgiou AA, Boudoulas $\mathrm{H}$, Kontopoulos AG. Long-term effect of converting enzyme inhibition on circadian sympathetic and parasympathetic modulation in patients with diabetic autonomic neuropathy. Acta Cardiol (1998) 53(4):201-9.

181. Gerstein HC. Reduction of cardiovascular events and microvascular complications in diabetes with ACE inhibitor treatment: HOPE and MICRO-HOPE. Diabetes Metab Res Rev (2002) 18(Suppl 3):S82-5. doi:10.1002/dmrr.285

182. Yamamoto R, Rakugi H. ACE Insertion/Deletion Polymorphism and Cardiovascular Effect of Hypercholesterolemia. J Atheroscler Thromb (2015) 22(4):338-41. doi:10.5551/jat.ED012

183. Jacobsen PK, Tarnow L, Parving H-H. Time to consider ACE insertion/deletion genotypes and individual renoprotective treatment in diabetic nephropathy? Kidney Int (2006) 69(8):1293-5. doi:10.1038/sj.ki.5000283

184. Ruggenenti P, Bettinaglio P, Pinares F, Remuzzi G. Angiotensin converting enzyme insertion/deletion polymorphism and renoprotection in diabetic and nondiabetic nephropathies. Clin J Am Soc Nephrol (2008) 3(5):1511-25. doi:10.2215/CJN.04140907

185. Scharplatz M, Puhan MA, Steurer J, Perna A, Bachmann LM. Does the angiotensin-converting enzyme (ACE) gene insertion/deletion polymorphism modify the response to ACE inhibitor therapy? A systematic review. Curr Control Trials Cardiovasc Med (2005) 6:16. doi:10.1186/1468-6708-6-16

186. Jayapalan JJ, Muniandy S, Chan SP. Null association between ACE gene I/D polymorphism and diabetic nephropathy among multiethnic Malaysian subjects. Indian J Hum Genet (2010) 16:78-86. doi:10.4103/0971-6866.69351

187. Parving HH, DeZD, Cooper ME, Remuzzi G, Liu N, Lunceford J, et al. ACE gene polymorphism and losartan treatment in type 2 diabetic patients with nephropathy. J Am Soc Nephrol (2008) 19(4):771-9. doi:10.1681/ASN.2007050582

188. Chung SS, Chung SK. Genetic analysis of aldose reductase in diabetic complications. Curr Med Chem (2003) 10:1375-87. doi:10.2174/0929867033457322

189. Sivenius K, Niskanen L, Voutilainen-Kaunisto R, Laakso M, Uusitupa $\mathrm{M}$. Aldose reductase gene polymorphisms and susceptibility to microvascular complications in type 2 diabetes. Diabet Med (2004) 21:1325. doi:10.1111/j.1464-5491.2004.01345.x

190. Yang B. Functional differences between the susceptibility Z-2/C-106 and protective $\mathrm{Z}+2 / \mathrm{T}-106$ promoter region polymorphisms of the aldose reductase gene may account for the association with diabetic microvascular complications. Biochim Biophys Acta (2003) 1639(1):1-7. doi:10.1016/ S0925-4439(03)00095-4

191. So W-Y, Wang Y, Ng M, Yang X, Ma R, Lam V, et al. Aldose reductase genotypes and cardiorenal complications. Diabetes Care (2008) 31(11):2148-53. doi: $10.2337 / \mathrm{dc} 08-0712$

192. Watarai A, Nakashima E, Hamada Y, Watanabe G, Naruse K, Miwa K, et al. Aldose reductase gene is associated with diabetic macroangiopathy in Japanese type 2 diabetic patients. Diabet Med (2006) 23(8):894-9. doi:10.1111/j.1464-5491.2006.01946.x
193. Shimizu H, Ohtani K-I, Tsuchiya T, Sato N, Tanaka Y, Takahashi H, et al. Aldose reductase mRNA expression is associated with rapid development of diabetic microangiopathy in Japanese type 2 diabetic (T2DM) patients. Diabetes Nutr Metab (2000) 13:75-9.

194. Kasajima H, Yamagishi S-I, Sugai S, Yagihashi N, Yagihashi S. Enhanced in situ expression of aldose reductase in peripheral nerve and renal glomeruli in diabetic patients. Virchows Arch (2001) 439(1):46-54. doi:10.1007/s004280100444

195. Ichikawa F, Yamada K, Ishiyama-Shigemoto S, Yuan X, Nonaka K. Association of an (A-C)n dinucleotide repeat polymorphic marker at the $5^{\prime}$-region of the aldose reductase gene with retinopathy but not with nephropathy or neuropathy in Japanese patients with type 2 diabetes mellitus. Diabet Med (1999) 16(9):744-8. doi:10.1046/j.1464-5491.1999.00155.x

196. Heesom AE, Millward A, Demaine AG. Susceptibility to diabetic neuropathy in patients with insulin dependent diabetes mellitus is associated with a polymorphism at the 5' end of the aldose reductase gene. J Neurol Neurosurg Psychiatry (1998) 64(2):213-6. doi:10.1136/jnnp.64.2.213

197. Oates PJ. Aldose reductase inhibitors and diabetic kidney disease. Curr Opin Investig Drugs (2010) 11(4):402-17.

198. Oates PJ. Aldose reductase, still a compelling target for diabetic neuropathy. Curr Drug Targets (2008) 9(1):14-36. doi:10.2174/138945008783431781

199. Chalk C, Benstead TJ, Moore F. Aldose reductase inhibitors for the treatment of diabetic polyneuropathy. Cochrane Database Syst Rev (2007) 4:CD004572. doi:10.1002/14651858.CD004572.pub2

200. Schemmel KE, Padiyara RS, D'Souza JJ. Aldose reductase inhibitors in the treatment of diabetic peripheral neuropathy: a review. J Diabetes Complications (2010) 24:354-60. doi:10.1016/j.jdiacomp.2009.07.005

201. Faes T, Yff G, DeWeerdt O, Lanting P, Heimans J, Bertelsmann F. Treatment of diabetic autonomic neuropathy with an aldose reductase inhibitor. J Neurol (1993) 240(3):156-60. doi:10.1007/BF00857521

202. Oishi N, Kubo E, Takamura Y, Maekawa K, Tanimoto T, Akagi Y. Correlation between erythrocyte aldose reductase level and human diabetic retinopathy. $\mathrm{Br}$ J Ophthalmol (2002) 86(12):1363-6. doi:10.1136/bjo.86.12.1363

203. Nicolucci A, Carinci F, Cavaliere D, Scorpiglione N, Belfiglio M, Labbrozzi D, et al. A meta-analysis of trials on aldose reductase inhibitors in diabetic peripheral neuropathy. The Italian Study Group. The St. Vincent Declaration. Diabet Med (1996) 13(12):1017-26. doi:10.1002/ (SICI) 1096-9136(199612)13:12<1017::AID-DIA252>3.0.CO;2-Z

204. Sima AA, Bril V, Nathaniel V, McEwen TA, Brown MB, Lattimer SA, et al. Regeneration and repair of myelinated fibers in sural-nerve biopsy specimens from patients with diabetic neuropathy treated with sorbinil. NEngl J Med (1988) 319(9):548-55. doi:10.1056/NEJM198809013190905

205. Várkonyi T, Kempler P. Diabetic neuropathy: new strategies for treatment. Diabetes Obes Metab (2008) 10(2):99-108. doi:10.1111/j.1463-1326.2007.00741.x

206. Suzen S, Buyukbingol E. Recent studies of aldose reductase enzyme inhibition for diabetic complications. Curr Med Chem (2003) 10(15):1329-52. doi:10.2174/0929867033457377

207. Hotta N, Kawamori R, Fukuda M, Shigeta Y. Long-term clinical effects of epalrestat, an aldose reductase inhibitor, on progression of diabetic neuropathy and other microvascular complications: multivariate epidemiological analysis based on patient background factors and severity of diabetic neurop. Diabet Med (2012) 29(12):1529-33. doi:10.1111/j.1464-5491.2012.03684.x

208. Hu X, Li S, Yang G, Liu H, Boden G, Li L. Efficacy and safety of aldose reductase inhibitor for the treatment of diabetic cardiovascular autonomic neuropathy: systematic review and meta-analysis. PLoS One (2014) 9(2):e87096. doi:10.1371/ journal.pone.0087096

209. Iso K, Tada H, Kuboki K, Inokuchi T. Long-term effect of epalrestat, an aldose reductase inhibitor, on the development of incipient diabetic nephropathy in type 2 diabetic patients. J Diabetes Complications (2001) 15(5):241-4. doi:10.1016/ S1056-8727(01)00160-X

210. Tabatabaei-Malazy O, Fakhrzadeh H, Qorbani M, Amiri P, Larijani B, Tavakkoly-Bazzaz J, et al. Apolipoprotein E gene polymorphism and its effect on anthropometric measures in normoglycemic subjects and type 2 diabetes. J Diabetes Metab Disord (2012) 11:18. doi:10.1186/2251-6581-11-18

211. Mahley RW. Apolipoprotein E: cholesterol transport protein with expanding role in cell biology. Science (1988) 240:622-30. doi:10.1126/ science. 3283935

212. Bedlack RS, Strittmatter WJ, Morgenlander JC. Apolipoprotein E and neuromuscular disease. Arch Neurol (2000) 57(11):2-6. doi:10.1001/archneur.57.11.1561 
213. Ukkola O, Kervinen K, Salmela PI, von Dickhoff K, Laakso M, Kesäniemi YA. Apolipoprotein E phenotype is related to macro- and microangiopathy in patients with non-insulin-dependent diabetes mellitus. Atherosclerosis (1993) 101:9-15. doi:10.1016/0021-9150(93)90096-D

214. Mahley RW, Weisgraber KH, Huang Y. Apolipoprotein E: structure determines function, from atherosclerosis to Alzheimer's disease to AIDS. J Lipid Res (2009) 50(Suppl):S183-8. doi:10.1194/jlr.R800069-JLR200

215. Teasdale GM, Nicoll JA, Murray G, Fiddes M. Association of apolipoprotein E polymorphism with outcome after head injury. Lancet (1997) 350:1069-71. doi:10.1016/S0140-6736(97)04318-3

216. Pritchard AL, Harris J, Pritchard CW, Coates J, Haque S, Holder R, et al. The effect of the apolipoprotein E gene polymorphisms and haplotypes on behavioural and psychological symptoms in probable Alzheimer's disease. J Neurol Neurosurg Psychiatry (2007) 78:123-6. doi:10.1136/jnnp.2006.092122

217. Araki S. APOE polymorphism and diabetic nephropathy. Clin Exp Nephrol (2014) 18(2):230-3. doi:10.1007/s10157-013-0862-0

218. Zhou Z, Hoke A, Cornblath DR, Griffin JW, Polydefkis M. APOE epsilon4 is not a susceptibility gene in idiopathic or diabetic sensory neuropathy. Neurology (2005) 64:139-41. doi:10.1212/01.WNL.0000148587.97690.4E

219. Hinder LM, Vincent AM, Hayes JM, McLean LL, Feldman EL. Apolipoprotein E knockout as the basis for mouse models of dyslipidemia-induced neuropathy. Exp Neurol (2013) 239:102-10. doi:10.1016/j.expneurol.2012.10.002

220. Melemedjian OK, Yassine HN, Shy A, Price TJ. Proteomic and functional annotation analysis of injured peripheral nerves reveals ApoE as a protein upregulated by injury that is modulated by metformin treatment. Mol Pain (2013) 9(1):14 . doi:10.1186/1744-8069-9-14

221. Villeneuve S, Brisson D, Marchant NL, Gaudet D. The potential applications of apolipoprotein E in personalized medicine. Front Aging Neurosci (2014) 6:154. doi:10.3389/fnagi.2014.00154

222. Tamasawa N, Murakami H, Yamato K, Matsui J, Tanabe J, Suda T. Influence of apolipoprotein $\mathrm{E}$ genotype on the response to caloric restriction in type 2 diabetic patients with hyperlipidaemia. Diabetes Obes Metab (2003) 5(5):345-8. doi:10.1046/j.1463-1326.2003.00286.x

223. Donnelly LA, Palmer CN, Whitley AL, Lang CC, Doney AS, Morris AD, et al. Apolipoprotein E genotypes are associated with lipid-lowering responses to statin treatment in diabetes: a Go-DARTS study. Pharmacogenet Genomics (2008) 18(4):279-87. doi:10.1097/FPC.0b013e3282f60aad

224. Comley LH, Fuller HR, Wishart TM, Mutsaers CA, Thomson D, Wright AK, et al. ApoE isoform-specific regulation of regeneration in the peripheral nervous system. Hum Mol Genet (2011) 20(12):2406-21. doi:10.1093/hmg/ddr147

225. Li F-Q, Fowler KA, Neil JE, Colton CA, Vitek MP. An apolipoprotein E-mimetic stimulates axonal regeneration and remyelination after peripheral nerve injury. J Pharmacol Exp Ther (2010) 334(1):106-15. doi:10.1124/jpet.110.167882

226. Mega JL, Morrow DA, Brown A, Cannon CP, Sabatine MS. Identification of genetic variants associated with response to statin therapy. Arterioscler Thromb Vasc Biol (2009) 29(9):1310-5. doi:10.1161/ATVBAHA.109.188474

227. Vrablík M, Hubácek JA, Dlouhá D, Lánská V, Rynekrová J, Zlatohlávek L, et al. Impact of variants within seven candidate genes on statin treatment efficacy. Physiol Res (2012) 61(6):609-17.

228. Superko HR, Momary KM, Li Y. Statins personalized. Med Clin North Am (2012) 96(1):123-39. doi:10.1016/j.mcna.2011.11.004

229. Saito M, Eto M, Nitta H, Kanda Y, Shigeto M, Nakayama K, et al. Effect of apolipoprotein E4 allele on plasma LDL cholesterol response to diet therapy in type 2 diabetic patients. Diabetes Care (2004) 27(6):1276-80. doi:10.2337/ diacare.27.6.1276

230. Zhong J-H, Rodriguez AC, Yang N-N, Li L-Q. Methylenetetrahydrofolate reductase gene polymorphism and risk of type 2 diabetes mellitus. PLoS One (2013) 8(9):e74521. doi:10.1371/journal.pone.0074521

231. Jacques PF, Bostom AG, Williams RR, Ellison RC, Eckfeldt JH, Rosenberg IH, et al. Relation between folate status, a common mutation in methylenetetrahydrofolate reductase, and plasma homocysteine concentrations. Circulation (1996) 93:7-9. doi:10.1161/01.CIR.93.1.7

232. Tanaka T, Scheet P, Giusti B, Bandinelli S, Piras MG, Usala G, et al. Genome-wide association study of vitamin B6, vitamin B12, folate, and homocysteine blood concentrations. Am J Hum Genet (2009) 84:477-82. doi:10.1016/j.ajhg.2009.02.011

233. Donnelly JG. Folic acid. Crit Rev Clin Lab Sci (2001) 38:183-223. doi:10.1080/20014091084209
234. D’Angelo A, Coppola A, Madonna P, Fermo I, Pagano A, Mazzola G, et al. The role of vitamin B12 in fasting hyperhomocysteinemia and its interaction with the homozygous C677T mutation of the methylenetetrahydrofolate reductase (MTHFR) gene A case-control study of patients with early-onset thrombotic events. Thromb Haemost (2000) 83(4):520-70.

235. Wang XW, Luo YL, Wang W, Zhang Y, Chen Q, Cheng YL. Association between MTHFR A1298C polymorphism and neural tube defect susceptibility: a metaanalysis. Am J Obstet Gynecol (2012) 206(3):e1-7. doi:10.1016/j. ajog.2011.12.021

236. Schlussel E, Preibisch G, Putter S, Elstner EF. Homocysteine-induced oxidative damage: mechanisms and possible roles in neurodegenerative and atherogenic processes. Z Naturforsch C (1995) 50:699-707.

237. Tutuncu NB, Erbas T, Alikasifoglu M, Tuncbilek E. Thermolabile methylenetetrahydrofolate reductase enzyme genotype is frequent in type 2 diabetic patients with normal fasting homocysteine levels. J Intern Med (2005) 257:446-53. doi:10.1111/j.1365-2796.2005.01480.x

238. Sonkar S, Sonkar G, Soni D, Soni D, Usman K. Plasma homocysteine level and its clinical correlation with type 2 diabetes mellitus and its complications. Int J Diabetes Dev Ctries (2014) 34(1):3-6. doi:10.1007/s13410-013-0154-y

239. De Luis DA, Fernandez N, Arranz ML, Aller R, Izaola O, Romero E. Total homocysteine levels relation with chronic complications of diabetes, body composition, and other cardiovascular risk factors in a population of patients with diabetes mellitus type 2. J Diabetes Complications (2005) 19:42-6. doi:10.1016/j. jdiacomp.2003.12.003

240. Wang H, Fan D, Hong T. Is the C677T polymorphism in methylenetetrahydrofolate reductase gene or plasma homocysteine a risk factor for diabetic peripheral neuropathy in Chinese individuals? Neural Regen Res (2012) 7(30):2384-91. doi:10.3969/j.issn.1673-5374.2012.30.009

241. Yi F, Li PL. Mechanisms of homocysteine-induced glomerular injury and sclerosis. Am J Nephrol (2008) 28:254-64. doi:10.1159/000110876

242. Chico A, Pérez A, Córdoba A, Arcelús R, Carreras G, de Leiva A, et al. Plasma homocysteine is related to albumin excretion rate in patients with diabetes mellitus: a new link between diabetic nephropathy and cardiovascular disease? Diabetologia (1998) 41(6):684-93. doi:10.1007/s001250050969

243. Rahimi M, Hasanvand A, Rahimi Z, Vaisi-Raygani A, Mozafari H, Rezaei M, et al. Synergistic effects of the MTHFR C677T and A1298C polymorphisms on the increased risk of micro- and macro-albuminuria and progression of diabetic nephropathy among Iranians with type 2 diabetes mellitus. Clin Biochem (2010) 43(16-17):1333-9. doi:10.1016/j.clinbiochem.2010.08.019

244. Cohen JA, Jeffers BW, Stabler S, Schrier RW, Estascio R. Increasing homocysteine levels and diabetic autonomic neuropathy. Auton Neurosci (2001) 87:268-73. doi:10.1016/S1566-0702(00)00262-9

245. De Jager J, Kooy A, Lehert P, Wulffelé MG, van der Kolk J, Bets D, et al. Long term treatment with metformin in patients with type 2 diabetes and risk of vitamin B-12 deficiency: randomised placebo controlled trial. BMJ (2010) 340:c2181. doi:10.1136/bmj.c2181

246. Miranda-Massari JR, Gonzalez MJ, Jimenez FJ, Allende-Vigo MZ, Duconge J. Metabolic correction in the management of diabetic peripheral neuropathy: improving clinical results beyond symptom control. Curr Clin Pharmacol(2011) 6(4):260-73. doi:10.2174/157488411798375967

247. Nagele P, Zeugswetter B, Wiener C, Burger H, Hüpfl M, Mittlböck M, et al. Influence of methylenetetrahydrofolate reductase gene polymorphisms on homocysteine concentrations after nitrous oxide anesthesia. Anesthesiology (2008) 109(1):36-43. doi:10.1097/ALN.0b013e318178820b

248. Taflin H, Wettergren Y, Odin E, Carlsson G, Derwinger K. Gene polymorphisms MTHFRC677T and MTRA2756G as predictive factors in adjuvant chemotherapy for stage III colorectal cancer. Anticancer Res (2011) 31(9):3057-62.

249. Fisher M, Cronstein B. Meta-analysis of methylenetetrahydrofolate reductase (MTHFR) polymorphisms affecting methotrexate toxicity. J Rheumatol (2009) 36(3):539-45. doi:10.3899/jrheum.080576

250. Lin H, Chung C, Chang C, Wang M. Hyperhomocysteinemia, deep vein thrombosis and vitamin $\mathrm{B} 12$ deficiency in a metformin-treated diabetic patient. J Formos Med Assoc (2007) 106(9):774-8. doi:10.1016/S0929-6646(08)60039-X

251. Sato Y, Ouchi K, Funase Y, Yamauchi K, Aizawa T. Relationship between metformin use, vitamin B12 deficiency, hyperhomocysteinemia and vascular complications in patients with type 2 diabetes. Endocr J (2013) 60(12):1275-80. doi:10.1507/endocrj.EJ13-0332 
252. Maeda M, Fujio Y, Azuma J. MTHFR gene polymorphism and diabetic retinopathy. Curr Diabetes Rev (2006) 2(4):467-76. doi:10.2174/1573399810602040467

253. Rahimi Z, Rahimi Z, Shahvaisi-Zadeh F, Sadeghei S, Vessal M, Yavari N. eNOS $4 \mathrm{a} / \mathrm{b}$ polymorphism and its interaction with eNOS G894T variants in type 2 diabetes mellitus: modifying the risk of diabetic nephropathy. Dis Markers (2013) 34(6):437-43. doi:10.3233/DMA-130988

254. Förstermann U, Münzel T. Endothelial nitric oxide synthase in vascular disease: from marvel to menace. Circulation (2006) 113(13):1708-14. doi:10.1161/ CIRCULATIONAHA.105.602532

255. Asakimori Y, Yorioka N, Taniguchi Y, Ito T, Ogata S, Kyuden Y, et al. T(-786) $\rightarrow \mathrm{C}$ polymorphism of the endothelial nitric oxide synthase gene influences the progression of renal disease. Nephron (2002) 91:747-51. doi:10.1159/000065041

256. Ezzidi I, Mtiraoui N, Mohamed M, Mahjoub T, Kacem M, Almawi W. Association of endothelial nitric oxide synthase Glu298Asp, 4b/a, and -786T >C gene variants with diabetic nephropathy. J Diabetes Complications (2008) 22(5):331-8. doi:10.1016/j.jdiacomp.2007.11.011

257. Dellamea BS, Pinto LC, Leitão CB, Santos KG, Canani LH. Endothelial nitric oxide synthase gene polymorphisms and risk of diabetic nephropathy: a systematic review and meta-analysis. BMC Med Genet (2014) 15:9. doi:10.1186/1471-2350-15-9

258. Heltianu C, Guja C. Role of nitric oxide synthase family in diabetic neuropathy. J Diabetes Metab (2012) 1(S5):002. doi:10.4172/2155-6156.S5-002

259. Ahlawat A, Rana A, Goyal N, Sharma S. Potential role of nitric oxide synthase isoforms in pathophysiology of neuropathic pain. Inflammopharmacology (2014) 22(5):269-78. doi:10.1007/s10787-014-0213-0

260. Claybaugh T, Decker S, McCall K, Slyvka Y, Steimle J, Wood A, et al. L-arginine supplementation in type II diabetic rats preserves renal function and improves insulin sensitivity by altering the nitric oxide pathway. Int J Endocrinol (2014) 2014:171546. doi:10.1155/2014/171546

261. You H, Gao T, Cooper T, Morris S, Award A. Diabetic nephropathy is resistant to oral L-arginine or L-citrulline supplementation. Am J Physiol Renal Physiol (2014) 307(11):F1292-301. doi:10.1152/ajprenal.00176.2014

262. Cherla G, Jaimes EA. Role of L-arginine in the pathogenesis and treatment of renal disease. J Nutr (2004) 134(10 Suppl):2801S-6S.

263. Sadik N. L-arginine attenuates diabetic nephropathy in streptozotocin-induced diabetic rats. Egypt J Biochem Mol Biol (2008) 26(1):1-22. doi:10.4314/ejbmb. v26i1.35954

264. Carmeliet P, Storkebaum E. Vascular and neuronal effects of VEGF in the nervous system: implications for neurological disorders. Semin Cell Dev Biol (2002) 13(1):39-53. doi:10.1006/scdb.2001.0290

265. Leinninger GM, Vincent AM, Feldman EL. The role of growth factors in diabetic peripheral neuropathy. J Peripher Nerv Syst (2004) 9:26-53. doi:10.1111/j.1085-9489.2004.09105.x

266. Debette S, Visvikis-Siest S, Chen MH, Ndiaye NC, Song C, Destefano A, et al. Identification of cis-and trans-acting genetic variants explaining up to half the variation in circulating vascular endothelial growth factor levels. Circ Res (2011) 109:554-63. doi:10.1161/CIRCRESAHA.111.243790

267. Lieb W, Safa R, Benjamin EJ, Xanthakis V, Yin X, Sullivan LM, et al. Vascular endothelial growth factor, its soluble receptor, and hepatocyte growth factor: clinical and genetic correlates and association with vascular function. Eur Heart $J$ (2009) 30:1121-7. doi:10.1093/eurheartj/ehp007

268. Pantsulaia I, Trofimov S, Kobyliansky E, Livshits G. Heritability of circulating growth factors involved in the angiogenesis in healthy human population. Cytokine (2004) 27:152-8. doi:10.1016/j.cyto.2004.04.005

269. Berrahmoune H, Herbeth B, Lamont JV, Masson C, Fitzgerald PS, Visvikis-Siest S. Heritability for plasma VEGF concentration in the Stanislas family study. Ann Hum Genet (2007) 71:54-63. doi:10.1111/j.1469-1809.2006.00298.x

270. Motawi TK, Rizk SM, Ibrahim IA, El-Emady YF. Alterations in circulating angiogenic and anti-angiogenic factors in type 2 diabetic patients with neuropathy. Cell Biochem Funct (2014) 32:155-63. doi:10.1002/cbf.2987

271. Deguchi T, Hashiguchi T, Horinouchi S, Uto T, Oku H, Kimura K, et al. Serum VEGF increases in diabetic polyneuropathy, particularly in the neurologically active symptomatic stage. Diabet Med (2009) 26:247-52. doi:10.1111/j.1464-5491.2009.02680.x

272. Cameron N, Cotter M. Vascular changes in animal models of diabetic neuropathy. J Neurochem (2003) 85(Suppl 2):14-5. doi:10.1046/j.1471-4159.85.s2.14_3.x
273. Sondell M, Lundborg G, Kanje M. Vascular endothelial growth factor has neurotrophic activity and stimulates axonal outgrowth, enhancing cell survival and Schwann cell proliferation in the peripheral nervous system. J Neurosci (1999) 19:5731-40.

274. Tremolada G, Lattanzio R, Mazzolari G, Zerbini G. The therapeutic potential of VEGF inhibition in diabetic microvascular complications. Am J Cardiovasc Drugs (2007) 7:393-8. doi:10.2165/00129784-200707060-00002

275. Nakagawa T. Uncoupling of the VEGF-endothelial nitric oxide axis in diabetic nephropathy: an explanation for the paradoxical effects of VEGF in renal disease. Am JPhysiol Renal Physiol (2007) 292(6):F1665-72. doi:10.1152/ajprenal.00495.2006

276. Bonnefond A, Saulnier P-J, Stathopoulou MG, Grarup N, Ndiaye NC, Roussel $\mathrm{R}$, et al. What is the contribution of two genetic variants regulating VEGF levels to type 2 diabetes risk and to microvascular complications? PLoS One (2013) 8(2):e55921. doi:10.1371/journal.pone.0055921

277. Virgili G, Parravano M, Menchini F, Brunetti M. Antiangiogenic therapy with anti-vascular endothelial growth factor modalities for diabetic macular oedema. Cochrane Database Syst Rev (2012) 12(4):CD007419. doi:10.1002/14651858. CD007419.pub3

278. Osaadon P, Fagan X, Lifshitz T, Levy J. A review of anti-VEGF agents for proliferative diabetic retinopathy. Eye (2014) 28(5):510-20. doi:10.1038/eye.2014.13

279. Boltz A, Ruiß M, Jonas JB, Tao Y, Rensch F, Weger M, et al. Role of vascular endothelial growth factor polymorphisms in the treatment success in patients with wet age-related macular degeneration. Ophthalmology (2012) 119(8):1615-20. doi:10.1016/j.ophtha.2012.02.001

280. Hermann MM, Van Asten F, Muether PS, Smailhodzic D, Lichtner P, Hoyng CB, et al. Polymorphisms in vascular endothelial growth factor receptor 2 are associated with better response rates to ranibizumab treatment in age-related macular degeneration. Ophthalmology (2014) 121(4):905-10. doi:10.1016/j.ophtha.2013.10.047

281. Abedi F, Wickremasinghe S, Richardson AJ, Islam AF, Guymer RH, Baird PN. Genetic influences on the outcome of anti-vascular endothelial growth factor treatment in neovascular age-related macular degeneration. Ophthalmology (2013) 120(8):1641-8. doi:10.1016/j.ophtha.2013.01.014

282. Orlin A, Hadley D, Chang W, Ho AC, Brown G, Kaiser RS, et al. Association between high-risk disease loci and response to anti-vascular endothelial growth factor treatment for wet age-related macular degeneration. Retina (2012) 32(1):4-9. doi:10.1097/IAE.0b013e31822a2c7c

283. El-Shazly SF, El-Bradey MH, Tameesh MK. Vascular endothelial growth factor gene polymorphism prevalence in patients with diabetic macular edema and its correlation with anti-VEGF treatment outcomes. Clin Experiment Ophthalmol (2013) 42(4):369-78. doi:10.1111/ceo.12182

284. Kloeckener-Gruissem B, Barthelmes D, Labs S, Schindler C, Kurz-Levin M, Michels S, et al. Genetic association with response to intravitreal ranibizumab in patients with neovascular AMD. Investig Ophthalmol Vis Sci (2011) 52(7):4694-702. doi:10.1167/iovs.10-6080

285. Hagstrom S, Ying G-S, Pauer G, Sturgill-Short G, Huan J, Maguire M, et al. VEGF-A and VEGFR-2. JAMA Ophthalmol (2014) 132(5):521-7. doi:10.1001/ jamaophthalmol.2014.109

286. Smailhodzic D, Muether PS, Chen J, Kwestro A, Zhang AY, Omar A, et al. Cumulative effect of risk alleles in CFH, ARMS2, and VEGFA on the response to ranibizumab treatment in age-related macular degeneration. Ophthalmology (2012) 119(11):2304-11. doi:10.1016/j.ophtha.2012.05.040

287. Kessler J. Vascular endothelial growth factor gene transfer for diabetic polyneuropathy. Ann Neurol (2009) 65(4):362-4. doi:10.1002/ana.21686

288. Schratzberger P, Schratzberger G, Silver M, Curry C, Kearney M, Magner M, et al. Favorable effect of VEGF gene transfer on ischemic peripheral neuropathy. Nat Med (2000) 6(4):405-13. doi:10.1038/74664

289. Davì G, Tuttolomondo A, Santilli F, Basili S, Ferrante E, Di Raimondo D, et al. CD40 ligand and $\mathrm{MCP}-1$ as predictors of cardiovascular events in diabetic patients with stroke. J Atheroscler Thromb (2009) 16(6):707-13. doi:10.5551/jat.1537

290. Tuttolomondo A, La Placa S, Di Raimondo D, Bellia C, Caruso A, Lo Sasso B, et al. Adiponectin, resistin and IL-6 plasma levels in subjects with diabetic foot and possible correlations with clinical variables and cardiovascular co-morbidity. Cardiovasc Diabetol (2010) 9:50. doi:10.1186/1475-2840-9-50

291. Tuttolomondo A, Di Raimondo D, Forte GI, Casuccio A, Vaccarino L, Scola L, et al. Single nucleotide polymorphisms (SNPs) of pro-inflammatory/anti-inflammatory and thrombotic/fibrinolytic genes in patients with acute ischemic stroke 
in relation to TOAST subtype. Cytokine (2012) 58(3):398-405. doi:10.1016/j. cyto.2012.02.012

292. Al Safar H, Cordell H, Jafer O, Anderson D, Jamieson S, Fakiola M, et al. A genome-wide search for type 2 diabetes susceptibility genes in an extended Arab family. Ann Hum Genet (2013) 77:488-503. doi:10.1111/ahg.12036

293. Doria A. Genetics of diabetes complications. Curr Diab Rep (2010) 10(6):467-75. doi:10.1007/s11892-010-0147-x

294. Farbstein D, Levy A. The genetics of vascular complications in diabetes mellitus. Cardiol Clin (2010) 28(3):477-96. doi:10.1016/j.ccl.2010.04.005

295. McCarthy MI. Genomics, type 2 diabetes, and obesity. N Engl J Med (2010) 363(24):2339-50. doi:10.1056/NEJMra0906948

296. Settin A, El-Baz R, Ismaeel A, Tolba W, Allah WA. Association of ACE and MTHFR genetic polymorphisms with type 2 diabetes mellitus: susceptibility and complications. J Renin Angiotensin Aldosterone Syst (2014). doi:10.1177/1470320313516172

Conflict of Interest Statement: The authors declare that the research was conducted in the absence of any commercial or financial relationships that could be construed as a potential conflict of interest.

Copyright $\odot 2015$ Witzel, Jelinek, Khalaf, Lee, Khandoker and Alsafar. This is an open-access article distributed under the terms of the Creative Commons Attribution License (CC BY). The use, distribution or reproduction in other forums is permitted, provided the original author(s) or licensor are credited and that the original publication in this journal is cited, in accordance with accepted academic practice. No use, distribution or reproduction is permitted which does not comply with these terms. 